\title{
EFFECTS OF AGE AND KNEE OSTEOARTHRITIS ON THE MODULAR CONTROL OF WALKING: A PILOT STUDY
}

1,2Sarah A. Roelker, ${ }^{2}$ Rebekah R. Koehn, ${ }^{3}$ Elena J. Caruthers, ${ }^{4-6}$ Laura C. Schmitt, ${ }^{2,4-8}$ Ajit M.W. Chaudhari, ${ }^{2,4,5,7,8}$ Robert A. Siston

${ }^{1}$ Department of Mechanical Engineering, The University of Texas at Austin, Austin, TX, USA

${ }^{2}$ Department of Mechanical and Aerospace Engineering, The Ohio State University, Columbus, $\mathrm{OH}$, USA

${ }^{3}$ Department of Engineering, Otterbein University, Westerville, OH, USA

${ }^{4}$ School of Health and Rehabilitation Sciences, The Ohio State University, Columbus, $\mathrm{OH}, \mathrm{USA}$

${ }^{5}$ Sports Medicine Research Institute, The Ohio State University Wexner Medical Center, Columbus, OH, USA

${ }^{6}$ Division of Physical Therapy, School of Health and Rehabilitation Sciences, The Ohio State University, Columbus, $\mathrm{OH}$, USA

${ }^{7}$ Department of Biomedical Engineering, The Ohio State University, Columbus, $\mathrm{OH}$, USA

${ }^{8}$ Department of Orthopaedics, The Ohio State University, Columbus, OH, USA

Word count: 6245

Key Words: muscle synergy, motor control, co-activation, electromyography, gait

*Address Correspondence to:

Sarah A. Roelker

Department of Mechanical Engineering

ETC 3.110 Engineering Teaching Center II

204 E Dean Keeton St

Austin, TX 78712 USA

Phone: 513-446-3572

Email: sarah.schloemer@utexas.edu 
medRxiv preprint doi: https://doi.org/10.1101/2020.05.22.20110536; this version posted June 25, 2020. The copyright holder for this preprint (which was not certified by peer review) is the author/funder, who has granted medRxiv a license to display the preprint in perpetuity.

All rights reserved. No reuse allowed without permission.

\section{ABSTRACT}

Older adults and individuals with knee osteoarthritis $(\mathrm{KOA})$ often exhibit reduced locomotor function and altered muscle activity. Identifying age- and KOA-related changes to the modular control of gait may provide insight into the neurological mechanisms underlying reduced walking performance in these populations. The purpose of this pilot study was to determine if the modular control of walking differs between younger and older adults without KOA and adults with end-stage KOA. Kinematic, kinetic, and electromyography (EMG) data were collected from ten younger (23.9 \pm 2.8 years) and ten older (62.4 \pm 2.6 years) adults without KOA and ten KOA patients $(63.5 \pm 3.4$ years) walking at their self-selected speed. Separate non-negative matrix factorizations determined the number of modules required to reconstruct each participant's EMG. There was no significant difference $(p=0.056)$ in the number of required modules between younger adults $(4.1 \pm 1.0)$, older adults without KOA $(3.4 \pm 0.8)$, and KOA patients $(3.1 \pm$ 0.6). However, a significant association between module number and walking speed was observed $(r=0.401 ; p=0.028)$ and the KOA patients walked significantly slower $(1.01 \pm$ $0.16 \mathrm{~m} / \mathrm{s})$ than the younger adults $(1.24 \pm 0.18 \mathrm{~m} / \mathrm{s} ; p=0.026)$. In addition, KOA patients exhibited altered module activation timing profiles and composition (which muscles are associated with each module) characterized by increased muscle co-activity compared to unimpaired younger and older adults who required the same number of modules. Thus, disease-related changes in neuromuscular control strategy may be associated with functional deficits in KOA patients. 
medRxiv preprint doi: https://doi.org/10.1101/2020.05.22.20110536; this version posted June 25, 2020. The copyright holder for this preprint (which was not certified by peer review) is the author/funder, who has granted medRxiv a license to display the preprint in perpetuity.

\section{NEW AND NOTEWORTHY}

Differentiating between age- and disease-related changes in motor control may provide insight into mechanisms underlying impaired walking performance in individuals with knee osteoarthritis. There was no significant difference in the number of modules required by individuals with knee osteoarthritis and unimpaired younger and older adults. However, knee osteoarthritis patients exhibited altered module composition and timing characterized by increased muscle co-activity, which suggests a change in underlying neural control strategy may be associated with knee osteoarthritis. 
medRxiv preprint doi: https://doi.org/10.1101/2020.05.22.20110536; this version posted June 25, 2020. The copyright holder for this preprint (which was not certified by peer review) is the author/funder, who has granted medRxiv a license to display the preprint in perpetuity.

\section{INTRODUCTION}

Functional limitations, including difficulty walking, climbing stairs, or crouching, in community dwelling older adults aged have been shown to be predictive of future disability (Miller et al. 2000) as well as falls, pain, and medical expenses (Musich et al. 2018). Age-related changes in muscle function have been identified as the most important physiological change leading to functional limitations (Pendergast et al. 1993). Impaired neuromuscular activity has been identified as a cause of this altered muscle function (Clark et al. 2011, 2013). Furthermore, age-related differences in muscle activation patterns have been linked to altered gait kinematics and kinetics in older adults with no history of musculoskeletal injury or joint disorders (Judge et al. 1996; Kerrigan et al. 1998; Schmitz et al. 2009; Winter 1991). Older adults exhibit highly repeatable electromyography (EMG) signals, which suggests an inability to adapt their motor control to perturbations and reflects a loss of neural plasticity (Schmitz et al. 2009; Winter 1991). This age-related decrease in control complexity and adaptability of the nervous system may indicate that changes to the organization of the neural mechanisms underlying motor control are responsible for impaired functional performance in older adults.

Furthermore, it is important to differentiate between neuromuscular changes associated with normal aging and those associated with age-related disorders. For example, symptomatic knee osteoarthritis $(\mathrm{KOA})$ is a leading cause of disability in older adults (Guccione et al. 1993); yet, not all older adults develop KOA. Individuals with KOA have difficulty completing activities of daily living (Sugiura and Demura 2013) and walk with altered kinematics and kinetics compared to unimpaired age-matched individuals, including decreased peak knee flexion angle and peak knee flexion and extension 
medRxiv preprint doi: https://doi.org/10.1101/2020.05.22.20110536; this version posted June 25, 2020. The copyright holder for this preprint (which was not certified by peer review) is the author/funder, who has granted medRxiv a license to display the preprint in perpetuity.

All rights reserved. No reuse allowed without permission.

moments (Astephen et al. 2008a). KOA-related changes in joint mechanics have been suggested to be related to altered muscle activation patterns in the presence of KOA (Childs et al. 2004).

Several studies have identified altered muscle activation patterns in patients with KOA, which are suggestive of a disease-related loss of motor control complexity that may contribute to the observed changes in joint mechanics. For example, KOA patients exhibit increased co-contraction of the vastus medialis and medial gastrocnemius compared to unimpaired controls (Lewek et al. 2004). In addition, principal component analyses of vasti, hamstring, and gastrocnemius activation patterns from asymptomatic adults and individuals with mild to moderate (Kellgren-Lawrence (KL) grades I-III (Kellgren and Lawrence 1957)) (Astephen et al. 2008b; Hubley-Kozey et al. 2006) and severe (KL IV) KOA (Astephen et al. 2008b; Hubley-Kozey et al. 2008) revealed that a similar principal activation pattern captured the general spatiotemporal activation pattern of each muscle group across subject groups. However, subtle differences in the magnitude and shape of the activation patterns were capable of distinguishing between asymptomatic and KOA groups (Astephen et al. 2008b; Hubley-Kozey et al. 2006; Rutherford et al. 2013) and between KOA groups with different levels of structural severity (Astephen et al. 2008b; Rutherford et al. 2013). These differences between KOA and asymptomatic individuals' activation patterns may indicate changes in motor control strategy with increasing disease severity.

Current motor control theory suggests the underlying mechanisms controlling muscle activity during gait can be decomposed into a few "primitive signals" (Davis and Vaughan 1993; Ivanenko et al. 2004; Patla 1985) that represent basic central features of 
medRxiv preprint doi: https://doi.org/10.1101/2020.05.22.20110536; this version posted June 25, 2020. The copyright holder for this preprint (which was not certified by peer review) is the author/funder, who has granted medRxiv a license to display the preprint in perpetuity.

All rights reserved. No reuse allowed without permission.

the motor programs (Patla 1985). Muscles are grouped into modules (sometimes referred to as synergies) based on the similarity of their activation patterns to the temporal pattern of the primitive signals. A greater number of modules required to represent the original muscle activation patterns suggests a more complex neuromuscular control strategy (Clark et al. 2010). Weighting factors are assigned to the modules to quantify the strength of each muscle's representation within a given module. Modular organization (muscle weightings and temporal patterns) has been shown to be consistent across walking speeds in healthy adults regardless of factorization technique (Clark et al. 2010; Ivanenko et al. 2004), which indicates these modules are a robust representation of the underlying neuromuscular control of gait (Neptune et al. 2009).

Although modular control of gait has been characterized in healthy younger adults (age range: 26 to 42 years) (Ivanenko et al. 2004; Oliveira et al. 2013) and healthy older adults (63.1 \pm 9.1 years) (Allen and Neptune 2012; Clark et al. 2010; Neptune et al. 2009), differences in the factorization method and the number of muscles included in the factorization used to identify modules in younger and older adults may limit accurate comparison of the modular control of gait between age-groups. For example, by using experimental EMG from 16 muscles, five modules were previously identified to control gait in younger adults (Ivanenko et al. 2004; Oliveira et al. 2013). In contrast, four modules were identified in healthy older adults from the EMG of 8 muscles (Clark et al. 2010) while forward dynamic simulations of gait identified a fifth (Neptune et al. 2009) and sixth (Allen and Neptune 2012) module that describe the three-dimensional modular control of gait. While a qualitative comparison of the modules identified in these individual studies suggest the modular control of gait in older and younger adults is characterized 
medRxiv preprint doi: https://doi.org/10.1101/2020.05.22.20110536; this version posted June 25, 2020. The copyright holder for this preprint (which was not certified by peer review) is the author/funder, who has granted medRxiv a license to display the preprint in perpetuity.

All rights reserved. No reuse allowed without permission.

by similar temporal activation patterns and muscle weighting modules, only one study (Monaco et al. 2010) has directly compared the modular control of gait between agegroups. Although Monaco et al. (2010) found no significant differences in module muscle weightings and temporal patterns between younger and older adults during gait, the authors prescribed the number of modules extracted to be equal to 5 for all subjects prior to performing their factor analysis, which may have hindered their ability to identify differences in modular control between age-groups.

Alternatively, other studies of age-related differences in neuromuscular control suggest older adults utilize altered modular control strategies. Investigations of agerelated differences in muscle synergies controlling postural responses during step preparation demonstrated diminished control of gait initiation in older adults compared to younger adults (Wang et al. 2013, 2017), which suggests that aging may alter modular control of locomotor tasks. In addition, analyses of upper limb muscle modules during a pointing task found reduced modular control complexity (fewer modules) in older adults compared to younger adults (Vernooij et al. 2016). Modular control analyses in populations with neuromuscular impairments, such as stroke and cerebral palsy, reveal reduced motor control complexity during both upper extremity tasks (Cheung et al. 2012; Roh et al. 2013; Tang et al. 2017) and gait (Clark et al. 2010; Steele et al. 2015), which suggests populations exhibiting altered neuromuscular control in upper limb movements may also exhibit altered control of locomotion.

One recent study investigated the modular control of patients who had undergone a total knee arthroplasty (TKA), the end-stage treatment for KOA (Ardestani et al. 2017). Greater modular control complexity was observed in high-functioning compared to low- 
medRxiv preprint doi: https://doi.org/10.1101/2020.05.22.20110536; this version posted June 25, 2020. The copyright holder for this preprint (which was not certified by peer review) is the author/funder, who has granted medRxiv a license to display the preprint in perpetuity.

All rights reserved. No reuse allowed without permission.

functioning TKA patients, although both TKA groups exhibited reduced complexity compared to unimpaired controls (Ardestani et al. 2017). However, whether modular control was altered due to the disease prior to surgery or was altered as a result of surgery is unknown. It is possible that the observed differences between KOA and asymptomatic individuals' muscle activation patterns (Astephen et al. 2008b; Hubley-Kozey et al. 2006; Rutherford et al. 2013) are due to changes in the underlying motor control strategy.

Together, the altered muscle activity observed in older adults compared to younger adults and in patients with KOA compared to unimpaired older adults suggests that modular control may differ between age groups as well as between healthy and impaired older adults. Identifying age- and pathology-related changes to the modular control of gait may provide insight into the neurological mechanisms underlying reduced locomotor performance. Therefore, the purpose of this pilot study was to determine if the modular control of gait differs between healthy younger and older adults and between healthy older adults and patients with end-stage KOA. We hypothesized that there would be no differences in locomotor complexity, quantified by the number of modules required to reconstruct the experimental activation patterns, between younger and older adults without KOA, but that the modular organization of the older adults would be different than the younger adults. In addition, we hypothesized that the muscle activation patterns of patients with end-stage KOA would reduce to fewer modules than that of the younger and older adults without KOA, representing a reduction in neuromuscular control complexity.

\section{METHODS}

Data Collection 
medRxiv preprint doi: https://doi.org/10.1101/2020.05.22.20110536; this version posted June 25, 2020. The copyright holder for this preprint (which was not certified by peer review) is the author/funder, who has granted medRxiv a license to display the preprint in perpetuity. All rights reserved. No reuse allowed without permission.

Data from ten younger adults ( 5 female; $23.9 \pm 2.8$ years; $1.8 \pm 0.1 \mathrm{~m} ; 70.6 \pm 10.9$ $\mathrm{kg}$ ), ten unimpaired older adults ( 5 female; $62.7 \pm 2.6$ years; $1.7 \pm 0.1 \mathrm{~m} ; 73.0 \pm 13.1 \mathrm{~kg}$ ), and ten patients with primarily medial compartment KOA who were scheduled for a total knee arthroplasty within the following 8 weeks (7 female; $63.5 \pm 3.4$ years; $1.7 \pm 0.1 \mathrm{~m}$; $89.6 \pm 7.4 \mathrm{~kg}$ ) were included in this study as a secondary analysis of previously collected data. All participants provided written informed consent prior to participating in the data collection. All study procedures were approved by The Ohio State University Institutional Review Board. All participants performed at least five over-ground walking trials at their self-selected speeds. Self-selected speed was calculated as the distance between heelmarkers during consecutive ipsilateral heel-strikes divided by the time between heelstrikes. Skin-mounted reflective markers were applied to the upper and lower extremities according to the modified Full-Body Point-Cluster Technique (PCT) to measure full body kinematics (Andriacchi et al. 1998; Jamison et al. 2012). The three-dimensional trajectories of the reflective markers were collected at $150 \mathrm{~Hz}$ using ten Vicon MX-F40 cameras (Vicon, Los Angeles, CA). An embedded-force-plate walkway formed by 6 force platforms (Bertec, Columbus, OH) collected ground reaction forces (GRFs) at $1500 \mathrm{~Hz}$. Surface electromyography (EMG) (Telemyo DTS System, Noraxon, Scottsdale, AZ) was collected at $1500 \mathrm{~Hz}$ from 8 muscles on each participant's dominant (younger and older adults) or involved (KOA) limb to measure muscle activation patterns from the rectus femoris, vastus lateralis, vastus medialis, biceps femoris, medial hamstrings, lateral gastrocnemius, medial gastrocnemius, and soleus. The skin over each muscle was prepared by shaving hair from the skin and cleansing the area with alcohol. $\mathrm{Ag} / \mathrm{AgCl}$ dualelectrodes (Vermed, Buffalo, NY, Peripheral Nerve Stimulation Dual Element Electrodes, 
medRxiv preprint doi: https://doi.org/10.1101/2020.05.22.20110536; this version posted June 25, 2020. The copyright holder for this preprint (which was not certified by peer review) is the author/funder, who has granted medRxiv a license to display the preprint in perpetuity.

All rights reserved. No reuse allowed without permission.

rectangular, 1.625 in x 3.25 in, 0.42 in sensor diameter, 1.625 in inter-electrode distance) were placed over the muscle belly of each muscle. To determine the dominant limb of the healthy younger and older adults, each participant was asked which leg he or she would use to kick a ball (van Melick et al. 2017).

\section{KOA-Specific Data Collection}

The KOA patients included in this study are a subset of participants from a larger study investigating gait biomechanics before and after total knee arthroplasty (Freisinger et al. 2017). For each KOA patient, two fellowship-trained, musculoskeletal radiologists graded the patient's tibiofemoral radiographic severity using the $\mathrm{KL}$ grading system (Kellgren and Lawrence 1957) by consensus. In addition to the walking trials, the KOA patients performed three clinical performance-based assessments: the six-minute walk test (6MW) (Enright 2003), the timed stair climbing test (SCT) (Rejeski et al. 1995), and the timed-up and go test (TUG) (Dobson et al. 2013). Finally, KOA patient self-reported function was evaluated using four subscales of the Knee Injury and Osteoarthritis Outcome Score (KOOS) (Roos et al. 1998): pain, symptoms, activities of daily living $(A D L)$, and knee-related quality of life (QOL). The KOOS subscale responses were assigned a score from 0 to 4 by the patient and normalized for each subscale such that a higher score indicates better self-perceived function.

\section{Identification of Muscle Modules}

Nonnegative Matrix Factorization (NMF) (Lee and Seung 1999) was chosen to identify modules because it produces additive components that can be interpreted 
medRxiv preprint doi: https://doi.org/10.1101/2020.05.22.20110536; this version posted June 25, 2020. The copyright holder for this preprint (which was not certified by peer review) is the author/funder, who has granted medRxiv a license to display the preprint in perpetuity.

All rights reserved. No reuse allowed without permission.

physiologically (Ting et al. 2012) given that neuron firing rates are never negative and synaptic strengths do not change sign (Lee and Seung 1999). For each participant, EMG from a single complete gait cycle during a representative trial was chosen for NMF. The EMG were demeaned, passed through a $30-300 \mathrm{~Hz}$ sixth order Butterworth band-pass filter, and full wave rectified. The data were then passed through a sixth order Butterworth low-pass filter at $6 \mathrm{~Hz}$ to create linear envelopes. Each muscle's processed EMG was normalized to the maximum EMG from the trial. The normalized muscle activation patterns were combined into an $m x t$ matrix (EMGo), where $m$ indicates the number of muscles and $t$ includes the time points for the trial. The number of time points, $t$, was 201, accounting for every $0.5 \%$ of the gait cycle. An NMF algorithm defined by Lee and Seung (1999) was applied to the $m \times t$ matrix. NMF defines the modular organization by populating an $m \times n$ matrix representing the relative weighting of each muscle within each module (Weighting Matrix) and an $n \times t$ matrix reflecting the temporal activation of the module across the gait cycle (Pattern Matrix). NMF assumes that muscles may belong to more than one module and that the muscle weightings on each module are fixed throughout the gait cycle. The two matrices were multiplied to produce an $m \times t$ matrix of the reconstructed activation patterns $\left(E M G_{r}\right)$. A multiplicative update algorithm using 50 replicates and a maximum of 10000 iterations adjusted the muscle weightings and activation profiles to minimize the sum of squared errors between $E M G_{0}$ and $E M G_{r}$.

The number of modules required to adequately reconstruct the original activation patterns for each participant in each population were determined using separate NMF analyses, which were first run with the output constrained to one module. The percent 
medRxiv preprint doi: https://doi.org/10.1101/2020.05.22.20110536; this version posted June 25, 2020. The copyright holder for this preprint (which was not certified by peer review) is the author/funder, who has granted medRxiv a license to display the preprint in perpetuity.

variability accounted for (VAF; Equation 1) by the module was used as a measure of the agreement between the original and reconstructed activation patterns:

$$
V A F(\%)=\left(1-\frac{\left(E M G_{o}-E M G_{r}\right)^{2}}{E M G_{o}^{2}}\right) \times 100
$$

If the VAF was greater than $90 \%$ for each of the eight muscles, no additional modules were needed to represent the data. Otherwise, the number of modules included in the NMF was increased by one until the VAF of all eight muscles was greater than $90 \%$ or until the VAF was greater than $80 \%$ for all muscles and adding another module did not increase the VAF of the muscle with the lowest VAF by more than $5 \%$ of the previous VAF.

Module Analsyis

Each participant's principal patterns were normalized to the peak value so that the magnitude of each pattern ranged from 0 to 1. Similarly, each module's muscle weightings were normalized to the maximum muscle weight in the module, which resulted in a muscle weight of 1 for the muscle which had the greatest weighting in the module. For each participant population, the identified principal patterns and muscle weightings were averaged across participants within the population to determine population means and standard deviations. For all other modular control analyses, participants were sorted within their respective population according to the number of modules required to reconstruct their EMG (module group).

For module groups which contained more than one participant in all three populations, module activation timing profiles were compared using the area under the activation curve $(A \cup C)$ during five gait phases: weight acceptance $(0-15 \%$ gait cycle), 
medRxiv preprint doi: https://doi.org/10.1101/2020.05.22.20110536; this version posted June 25, 2020. The copyright holder for this preprint (which was not certified by peer review) is the author/funder, who has granted medRxiv a license to display the preprint in perpetuity.

All rights reserved. No reuse allowed without permission.

early midstance (15-30\% gait cycle), late midstance (30-50\% gait cycle), terminal stance (50-65\% gait cycle), and swing (65-100\% gait cycle). In addition, when module-group level comparisons could be made between all three populations, the module composition was compared between populations based on the number of significantly active muscles per module ( $\mathrm{W}_{\text {musc }}$ ) and the sum of the contributions of the significantly active muscles in a module ( $W_{\text {sum; }}$ i.e., the sum of the bar heights of the muscle weightings) (Hayes et al. 2014). Both $W_{\text {musc }}$ and $W_{\text {sum }}$ quantify the muscle co-activity of the module. A muscle was considered significantly active if the confidence interval for the muscle weighting did not include zero.

Joint Kinematic and Kinetic Analysis

Sagittal plane joint angle and internal joint moment profiles for the hip, knee, and ankle were determined for each participant and then averaged within each population and for each module group within a population. Joint moments were normalized by body weight, height, and self-selected walking speed. At the hip, peak angles were calculated for early stance hip flexion $(\mathrm{H} 1)$, late stance hip extension $(\mathrm{H} 2)$, and swing phase hip flexion (H3) and peak moments were calculated for early stance hip extension (HM1), late stance hip flexion (HM2), and swing phase hip extension (HM3). At the knee, peak angles were calculated for early stance knee flexion (K1), midstance knee extension (K2), and swing phase knee flexion (K3) and peak moments were calculated for weight acceptance knee flexion (KM1), early stance knee extension (KM2), midstance knee flexion (KM3), late stance knee extension (KM4), and swing phase knee flexion (KM5). At the ankle, peak angles were calcualted for early stance plantarflexion (A1), late stance dorsiflexion 
medRxiv preprint doi: https://doi.org/10.1101/2020.05.22.20110536; this version posted June 25, 2020. The copyright holder for this preprint (which was not certified by peer review) is the author/funder, who has granted medRxiv a license to display the preprint in perpetuity.

All rights reserved. No reuse allowed without permission.

(A2), push-off plantarflexion (A3), and swing phase dorsiflexion (A4) and peak moments were calculated for early stance dorsiflexion (AM1) and late stance plantarflexion (AM2). Peak measures were averaged across participants within each population and in each module group within a population.

\section{Statistics}

Individual one-way Analysis of Variance (ANOVA) tests were used to assess the effect of population on age, height, mass, body mass index (BMI), self-selected walking speed, stride length normalized to leg length, stance phase duration as a percentage of the gait cycle, the number of modules required to adequately reconstruct the EMG, the VAF of the muscle with the lowest VAF (minimum VAF) based on the number of modules extracted by NMF regardless of module group, and peak joint angles and moments. Individual one-way ANOVAs assessed the effect of population on $W_{\text {musc }}, W_{\text {sum, }}, A U C$, and peak joint kinematics and kinetics for module groups which contained multiple participants from all three populations. When appropriate, Tukey's post-hoc analyses were used to test for pairwise differences. For the KOA patients, Pearson correlation coefficients were calculated to assess the association between KOA module group and $\mathrm{KL}$ grade, clinical performance-based test scores, and KOOS scores. Similarly, for the set of all participants and each population individually, Pearson correlation coefficients were determined to assess the association between module group and self-selected walking speed. A significance level of $\alpha<0.05$ was set a priori for all statistical tests. All statistics analyses were performed in MATLAB 2016a (MathWorks, Natick, MA). 
medRxiv preprint doi: https://doi.org/10.1101/2020.05.22.20110536; this version posted June 25, 2020. The copyright holder for this preprint (which was not certified by peer review) is the author/funder, who has granted medRxiv a license to display the preprint in perpetuity.

All rights reserved. No reuse allowed without permission.

\section{RESULTS}

Population Average Demographics and Activation Patterns

Compared to the younger and older adults, the KOA patients had significantly greater mass (all $p \leq 0.002$ ) and BMI (all $p<0.001$ ) (Table 1). The KOA patients also walked significantly slower than the younger adults $(p=0.021)$. There was no statistically significant difference in age between the older adults and KOA patients $(p=1.000)$. As expected, the older adults and KOA patients were significantly older than the younger adults (all $p<0.001$ ). There were no differences between populations in normalized stride length (all $p \geq 0.184$ ) nor in stance phase duration $(p \geq 0.085)$.

The normalized EMG of the eight muscles exhibited similar activation patterns across populations (Figure 1). However, the normalized activation magnitude of the KOA patients tended to be higher during stance compared to that of the older and younger adults, particularly in the hamstrings (medial hamstrings and biceps femoris), the plantarflexors (medial gastrocnemius, lateral gastrocnemius, and soleus), and the rectus femoris, but not as much in the vastus medialis and lateralis. Swing phase activation magnitudes were similar across populations. 
medRxiv preprint doi: https://doi.org/10.1101/2020.05.22.20110536; this version posted June 25, 2020. The copyright holder for this preprint (which was not certified by peer review) is the author/funder, who has granted medRxiv a license to display the preprint in perpetuity. All rights reserved. No reuse allowed without permission.

Table 1: Population Demographics

\begin{tabular}{lcccc}
\hline & $\begin{array}{c}\text { Younger } \\
(\mathrm{n}=10)\end{array}$ & $\begin{array}{c}\text { Older } \\
(\mathrm{n}=10)\end{array}$ & $\begin{array}{c}\text { KOA } \\
(\mathrm{n}=10)\end{array}$ & p-Value \\
\hline Sex & $5 \mathrm{M}, 5 \mathrm{~F}$ & $5 \mathrm{M}, 5 \mathrm{~F}$ & $3 \mathrm{M}, 7 \mathrm{~F}$ & \\
\hline Age (years) & $23.5 \pm 3.1$ & $63.5 \pm 3.4$ & $63.5 \pm 3.4$ & $<0.001^{\mathrm{a}, \mathrm{b}}$ \\
\hline Height $(\mathrm{m})$ & $1.75 \pm 0.07$ & $1.69 \pm 0.08$ & $1.67 \pm 0.08$ & 0.06 \\
\hline Mass $(\mathrm{kg})$ & $71.2 \pm 10.0$ & $71.5 \pm 13.5$ & $89.6 \pm 7.4$ & $<0.001^{\mathrm{b}, \mathrm{c}}$ \\
\hline BMI $\left(\mathrm{kg} / \mathrm{m}^{2}\right)$ & $23.1 \pm 2.8$ & $24.8 \pm 2.6$ & $32.2 \pm 3.9$ & $<0.001^{\mathrm{b}, \mathrm{c}}$ \\
\hline Self-Selected Walking Speed $(\mathrm{m} / \mathrm{s})$ & $1.24 \pm 0.18$ & $1.12 \pm 0.18$ & $1.01 \pm 0.16$ & $0.026^{\mathrm{b}}$ \\
\hline Normalized Stride Length* & $1.63 \pm 0.17$ & $1.51 \pm 0.16$ & $1.49 \pm 0.19$ & 0.155 \\
\hline Stance Duration $(\%$ Gait Cycle) & $63.6 \pm 1.1$ & $64.7 \pm 1.5$ & $65.6 \pm 3.0$ & 0.102 \\
\hline Number of Modules & $4.1 \pm 1.0$ & $3.4 \pm 0.8$ & $3.1 \pm 0.9$ & 0.056 \\
\hline
\end{tabular}

* Stride length normalized to leg length.

Demographics reported as the population average \pm standard deviation. Symbols indicate statistical differences between:

a Younger and Older

b Younger and KOA

c Older and KOA
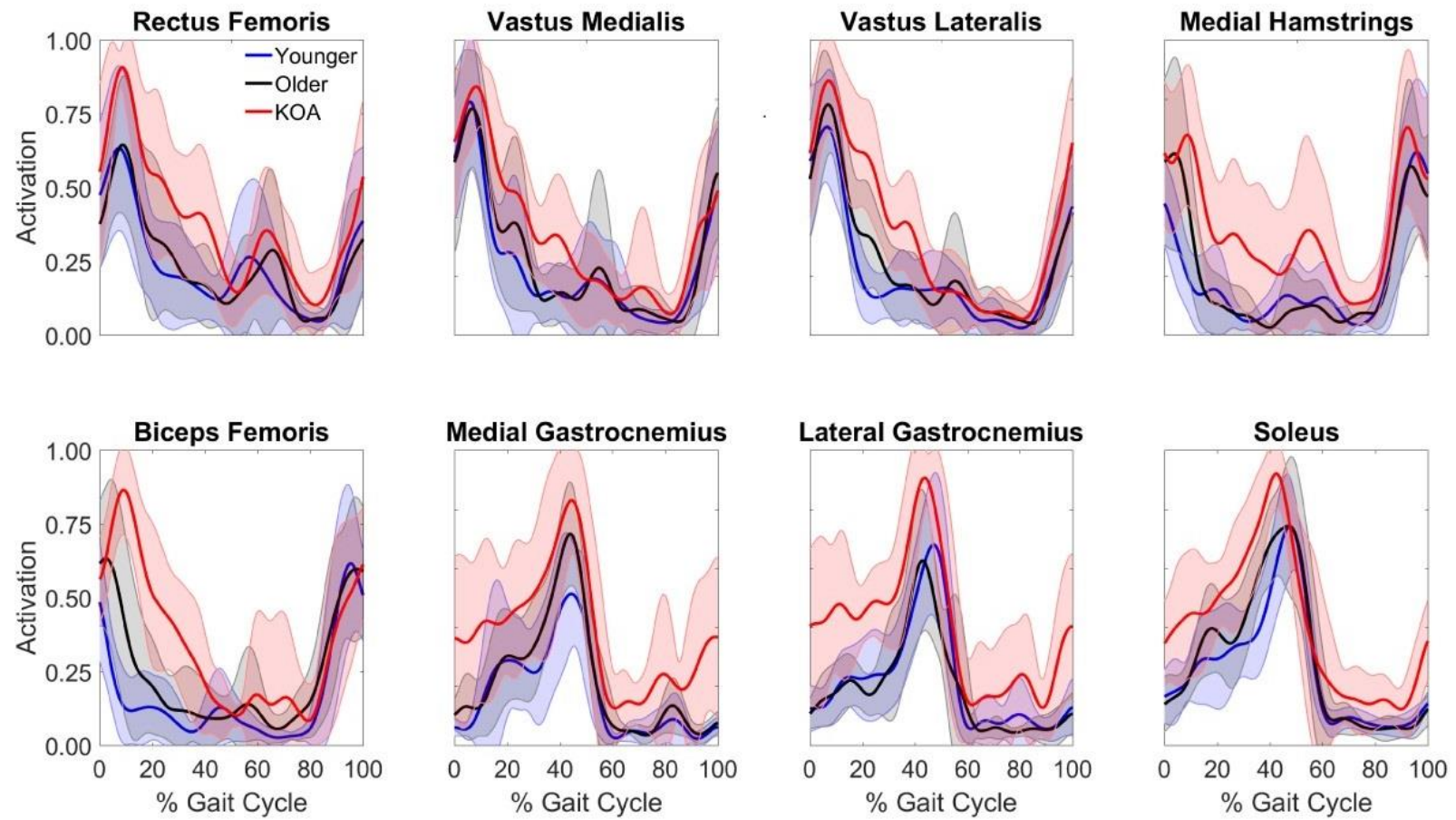

Figure 1: Average normalized EMG of young adults, older adults, and KOA patients. Solid lines represent population average. Shaded error bars represent \pm one standard deviation. 
medRxiv preprint doi: https://doi.org/10.1101/2020.05.22.20110536; this version posted June 25, 2020. The copyright holder for this preprint (which was not certified by peer review) is the author/funder, who has granted medRxiv a license to display the preprint in perpetuity.

\section{Modular Control Complexity}

There was no statistically significant difference between populations in the number of modules required to adequately reconstruct the original EMG activation patterns $(p=$ 0.056). However, there was a trend toward decreased control complexity from younger adults $(4.1 \pm 1.0$ modules $)$ to older adults $(3.4 \pm 0.8$ modules $)$ to KOA patients $(3.1 \pm 0.9$ modules). Of the 10 younger adults, three participants required three modules, four required four modules, two required five modules, and one required six modules. Of the 10 older adults, one participant required two modules, five required three modules, three required four modules, and one required five modules. Of the $10 \mathrm{KOA}$ patients, two participants required two modules, six required three modules, one required four modules, and one required five modules. There were significant differences in minimum VAF between populations when one, three, five, and six modules were extracted by NMF (Figure 2; all $p \leq 0.016$ ). When one module was extracted, KOA patients had significantly greater VAF than both younger $(p=0.002)$ and older $(p=0.002)$ adults. Younger adults had significantly lower VAF than KOA patients when three $(p=0.007)$, five $(p=0.003)$, and six $(p=0.016)$ modules were extracted.

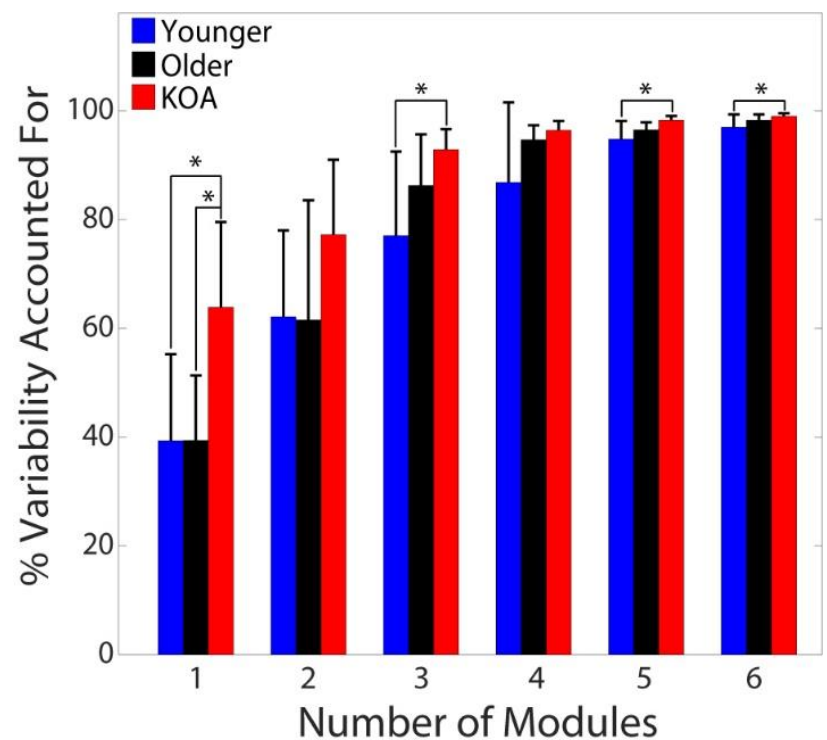

Figure 2: Average minimum percent VAF of each population based on the number of modules extracted by NMF. Error bars represent one standard deviation. * indicates pairwise differences between populations. 
medRxiv preprint doi: https://doi.org/10.1101/2020.05.22.20110536; this version posted June 25, 2020. The copyright holder for this preprint (which was not certified by peer review) is the author/funder, who has granted medRxiv a license to display the preprint in perpetuity.

All rights reserved. No reuse allowed without permission.

\section{Module Activation Timing and Composition between Populations}

Only the three module group included more than one participant from each population ( 3 younger adults, 5 older adults, and 6 KOA patients). Therefore, betweenpopulation module comparisons were made for only the three module group (Figure 3), which consisted of modules characterized by 1 ) early stance quadriceps activity (QUAD module), 2) late stance plantarflexor activity (PF module), and 3) weight acceptance and swing phase hamstrings activity (HAMS module). With respect to module activation timing (Figure $3 \mathrm{~A}$ ), during early midstance the KOA patients had greater area under the curve (Figure 3C) in the QUAD module than younger and older adults (all $p \leq 0.018$ ). During early midstance, there was also a significant main effect for population in the HAMS module $(p=0.043)$; however, the post-hoc test revealed no pairwise differences.
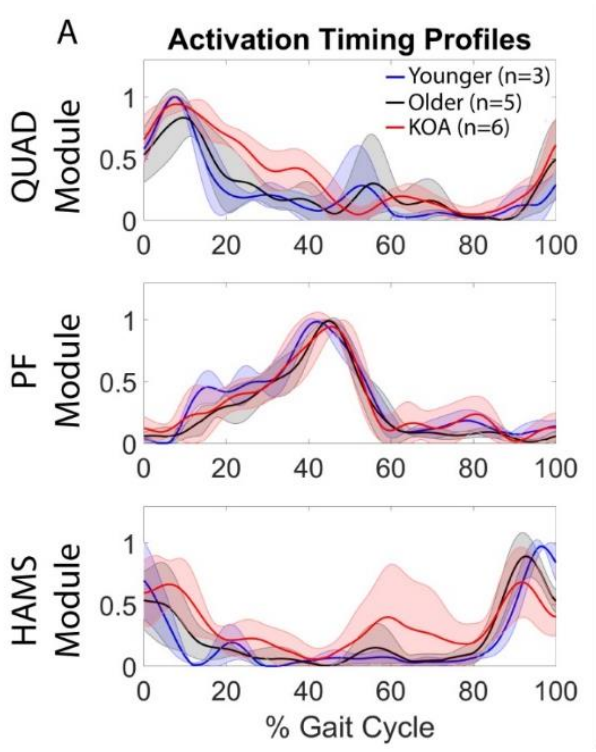
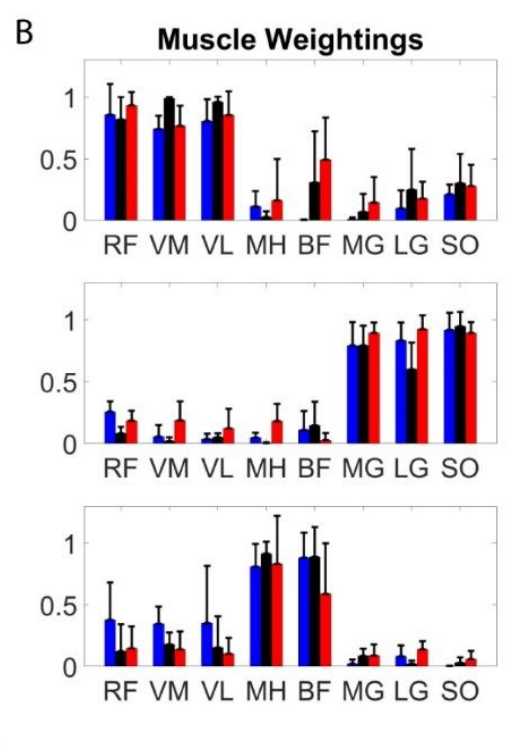

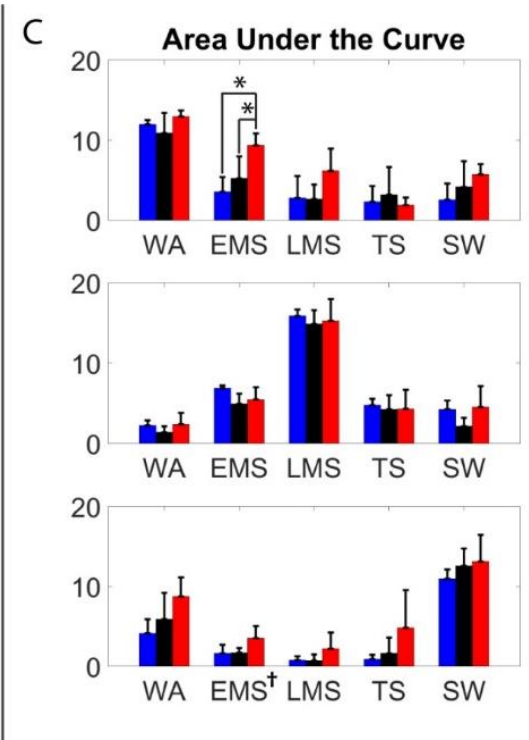

Figure 3: Module A) activation timing profiles, B) muscle weightings, and C) area under the curve for the three module group. For activation timing profiles, solid lines represent subject average and shaded error bars represent \pm one standard deviation. For muscle weightings, bars represent subject average and error bars represent one standard deviation. Muscle abbreviations: rectus femoris (RF), vastus medialis (VM), vastus lateralis $(\mathrm{VL})$, medial hamstrings $(\mathrm{MH})$, biceps femoris (BF), medial gastrocnemius (MG), lateral gastrocnemius (LG), and soleus (SO). Module name abbreviations: QUAD (quadriceps; RF, VM, and VL heavily weighted), PF (plantarflexors; MG, LG, and SO heavily weighted), and HAMS (hamstrings; MH and BF heavily weighted). Gait phase abbreviations: weight acceptance (WA), early midstance (EMS), late midstance (LMS), terminal stance (TS), and swing (SW). Symbols indicate: * statistically significant pairwise differences between populations, $\dagger$ statistically significant main effect of population but no pairwise differences. 
medRxiv preprint doi: https://doi.org/10.1101/2020.05.22.20110536; this version posted June 25, 2020. The copyright holder for this preprint (which was not certified by peer review) is the author/funder, who has granted medRxiv a license to display the preprint in perpetuity.

All rights reserved. No reuse allowed without permission.

In the three module group, the module composition described by the muscle weightings (Figure 3B) also differed between populations. The KOA patients had greater $W_{\text {musc }}$ than the younger and older adults for both the QUAD and PF modules (Table 2). For all three populations, rectus femoris, vastus medialis and lateralis, and soleus were significantly associated with the QUAD module (all $p \leq 0.047$ ). Only the KOA patients had two additional muscles, the biceps femoris $(p=0.016)$ and lateral gastrocnemius $(p=$ 0.024), which were also significantly associated with the QUAD module. The medial and lateral gastrocnemius, soleus, and rectus femoris were significantly associated with the PF module in all three populations (all $p \leq 0.035$ ). In the older adults the vastus lateralis $(p=0.031)$ was also significantly associated with the PF module while in the KOA patients the medial hamstring $(p=0.027)$ and vastus medialis $(p<0.033)$ were also significantly associated with the PF module. The KOA patients' greater $W_{\text {musc }}$ in the QUAD and PF modules corresponded to a significantly greater $W_{\text {sum }}$ (Figure 4) for the KOA patients compared to the younger adults $(p=0.022)$ and in the PF module compared to both younger and older adults (all $p \leq 0.043$ ). Although the older adults and KOA patients had a greater $W_{\text {musc }}$ than the younger adults for the HAMS module, there was no statistically significant difference in the HAMS module $\mathrm{W}_{\text {sum }}$ between populations (all $p>0.061$ ). For all three populations, the medial hamstrings and biceps femoris were significantly associated with the HAMS module (all $p \leq 0.017$ ). In the older adults, the vastus medialis $(p=0.016)$ and medial gastrocnemius $(p=0.032)$ were significantly associated with the HAMS module while in the KOA patients, the lateral gastrocnemius $(p=0.004)$ was significantly associated with the HAMS module. 
medRxiv preprint doi: https://doi.org/10.1101/2020.05.22.20110536; this version posted June 25, 2020. The copyright holder for this preprint (which was not certified by peer review) is the author/funder, who has granted medRxiv a license to display the preprint in perpetuity.

All rights reserved. No reuse allowed without permission.

Table 2: Muscles Significantly Associated with Three Module Group Modules by Population

\begin{tabular}{c|c|c|c|c|c|c|c|c|c|c}
\hline \multirow{2}{*}{ Module } & \multirow{2}{*}{ Population } & \multirow{2}{*}{$\mathbf{W}_{\text {musc }}$} & \multicolumn{7}{|c|}{ Muscle } \\
\cline { 4 - 11 } QUAD & & & RF & VM & VL & MH & BF & MG & LG & SO \\
\hline \multirow{3}{*}{ Pounger } & 4 & & & & & & & & \\
& Older & 4 & & & & & & & & \\
& KOA & 6 & & & & & & & & \\
\hline \multirow{3}{*}{ PF } & Younger & 4 & & & & & & & & \\
& Older & 5 & & & & & & & & \\
& KOA & 6 & & & & & & & & \\
\hline \multirow{3}{*}{ HAMS } & Younger & 2 & & & & & & & & \\
& Older & 4 & & & & & & & & \\
& KOA & 3 & & & & & & & & \\
\hline
\end{tabular}

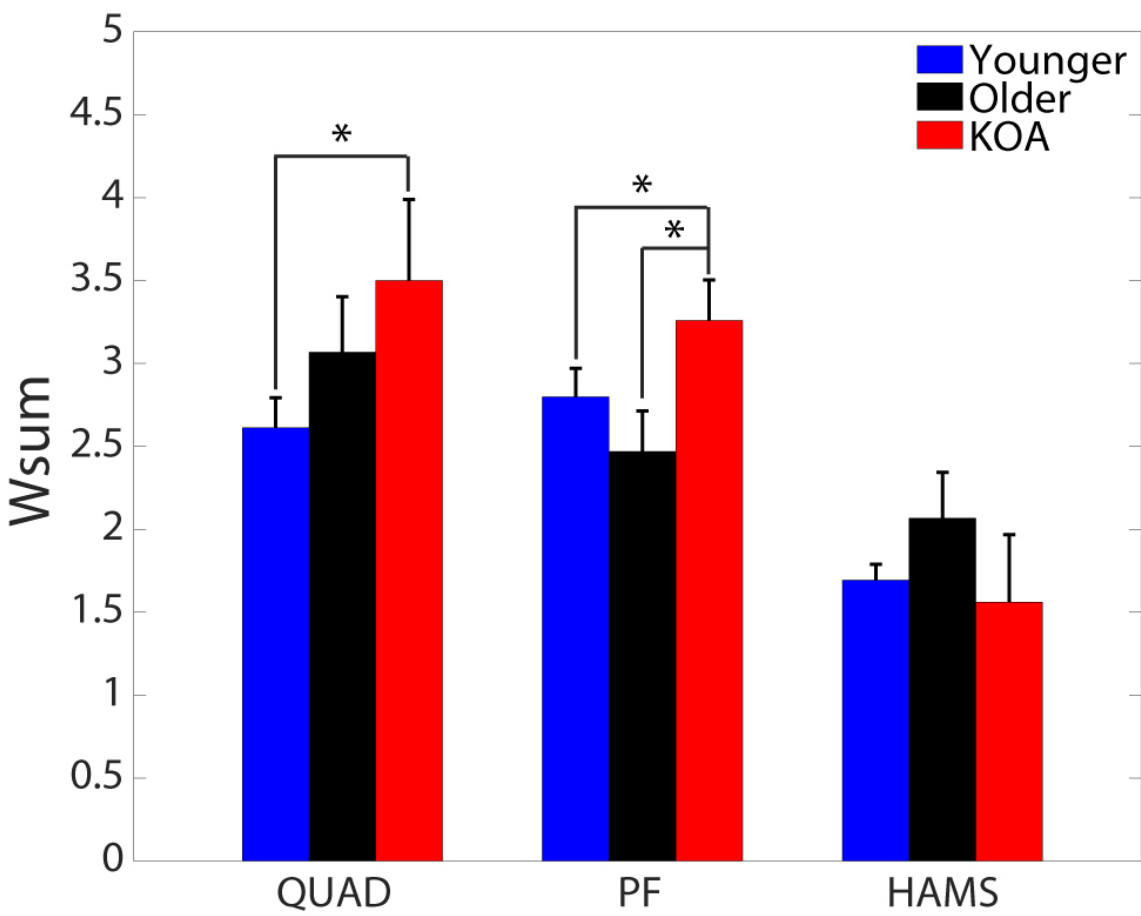

Figure 4: Summed muscle weightings for significantly active muscles $\left(\mathrm{W}_{\text {sum }}\right)$ in each module of the three module group for each population. * indicates statistically significant differences between populations.

The module activation timing profiles and muscle weightings for all other module groups are shown for comparison in the Appendix (Figure A1) along with the EMG patterns averaged across module groups (Figure A2). 
medRxiv preprint doi: https://doi.org/10.1101/2020.05.22.20110536; this version posted June 25, 2020. The copyright holder for this preprint (which was not certified by peer review) is the author/funder, who has granted medRxiv a license to display the preprint in perpetuity.

Joint Kinematics and Kinetics

There were several differences in peak joint kinematics and kinetics between populations (Table 3; Figure 5). Compared to the older adults and KOA patients, the younger adults had smaller peak hip flexion angles in early stance $(\mathrm{H} 1: p \leq 0.001)$ and swing (H3: $p \leq 0.002)$, greater hip extension (H2: $p \leq 0.002)$, less knee flexion in early stance (K1: $p \leq 0.045)$, greater knee extension (K2: $p \leq 0.001$ ), and less dorsiflexion during late stance (A2: $p \leq 0.033)$ and swing (A4: $p \leq 0.004)$. The older adults had a greater peak knee flexion angle during late stance than the younger adults and KOA patients (K3: $p \leq 0.001)$. The KOA patients had a smaller peak plantarflexion angle than the younger adults (A3: $p=0.022)$. With respect to joint kinetics, the younger adults had a greater midstance peak knee flexion (KM3: $p=0.001)$ moment than the KOA patients. Compared to the younger adults, the older adults had a smaller late swing peak hip extension moment (HM3: $p=0.049)$, a smaller peak weight acceptance knee flexion moment $(\mathrm{KM} 1: p=0.006)$, a greater early stance peak knee extension moment $(\mathrm{KM} 2: p$ $=0.035)$, and a greater late stance knee extension moment $(\mathrm{KM} 4: p=0.017)$. There were no differences between populations for all other peak joint angles and moments ( $p \geq$ 0.060). 
medRxiv preprint doi: https://doi.org/10.1101/2020.05.22.20110536; this version posted June 25, 2020. The copyright holder for this preprint (which was not certified by peer review) is the author/funder, who has granted medRxiv a license to display the preprint in perpetuity.

All rights reserved. No reuse allowed without permission.

Table 3: Peak Joint Angles and Moments

\begin{tabular}{|c|c|c|c|c|c|c|}
\hline Metric & Joint & Peak & Younger $(n=10)$ & Older $(n=10)$ & $\mathrm{KOA}(\mathrm{n}=10)$ & $p$-Value \\
\hline \multirow{10}{*}{ Angle $\left(^{\circ}\right)$} & \multirow{3}{*}{ Hip } & $\mathrm{H} 1$ & $24.8 \pm 3.9$ & $39.2 \pm 5.7$ & $37.7 \pm 6.6$ & $<0.001^{a, b}$ \\
\hline & & $\mathrm{H} 2$ & $-11.4 \pm 4.7$ & $-1.3 \pm 4.1$ & $1.5 \pm 8.3$ & $<0.001^{a, b}$ \\
\hline & & H3 & $31.5 \pm 5.8$ & $43.2 \pm 4.5$ & $40.2 \pm 5.0$ & $<0.001^{a, b}$ \\
\hline & \multirow{3}{*}{ Knee } & $\mathrm{K} 1$ & $9.9 \pm 8.0$ & $24.5 \pm 7.2$ & $19.1 \pm 8.9$ & $0.002^{a, b}$ \\
\hline & & $\mathrm{K} 2$ & $-1.5 \pm 5.7$ & $11.2 \pm 3.8$ & $12.8 \pm 9.9$ & $<0.001^{a, b}$ \\
\hline & & K3 & $62.8 \pm 3.8$ & $74.7 \pm 3.6$ & $62.9 \pm 6.6$ & $<0.001^{a, c}$ \\
\hline & \multirow{4}{*}{ Ankle } & A1 & $-9.4 \pm 3.9$ & $-5.4 \pm 3.8$ & $-6.1 \pm 3.9$ & 0.064 \\
\hline & & $\mathrm{A} 2$ & $4.7 \pm 5.3$ & $9.7 \pm 3.8$ & $14.1 \pm 3.1$ & $<0.001^{a, b}$ \\
\hline & & A3 & $-25.3 \pm 9.1$ & $-17.7 \pm 7.6$ & $-15.4 \pm 6.2$ & $0.022^{b}$ \\
\hline & & A4 & $-2.1 \pm 2.7$ & $2.8 \pm 3.5$ & $3.0 \pm 2.8$ & $0.001^{a, b}$ \\
\hline \multirow{10}{*}{$\begin{array}{c}\text { Moment } \\
\left(\times 10^{-2} \mathrm{Nm} / \mathrm{Nm}^{*} \mathrm{~m} / \mathrm{s}^{-1}\right)\end{array}$} & \multirow{3}{*}{ Hip } & HM1 & $3.9 \pm 1.1$ & $3.8 \pm 1.0$ & $4.0 \pm 1.8$ & 0.972 \\
\hline & & HM2 & $-4.1 \pm 0.7$ & $-3.0 \pm 0.9$ & $-3.5 \pm 1.9$ & 0.174 \\
\hline & & HM3 & $1.6 \pm 0.5$ & $0.9 \pm 0.6$ & $1.5 \pm 0.7$ & $0.045^{a}$ \\
\hline & \multirow{5}{*}{ Knee } & KM1 & $-1.9 \pm 1.0$ & $-0.7 \pm 0.7$ & $-1.4 \pm 0.6$ & $0.009^{a}$ \\
\hline & & KM2 & $1.2 \pm 1.5$ & $2.7 \pm 0.9$ & $2.4 \pm 1.6$ & $0.035^{a}$ \\
\hline & & KM3 & $-1.6 \pm 0.6$ & $-0.6 \pm 0.5$ & $0.1 \pm 1.4$ & $0.002^{b}$ \\
\hline & & KM4 & $1.0 \pm 0.4$ & $1.7 \pm 0.5$ & $1.4 \pm 0.6$ & $0.023^{a}$ \\
\hline & & KM5 & $-1.2 \pm 0.3$ & $-1.3 \pm 0.4$ & $-1.14 \pm 0.3$ & 0.398 \\
\hline & \multirow{2}{*}{ Ankle } & AM1 & $-1.1 \pm 0.3$ & $-1.0 \pm 0.4$ & $-0.8 \pm 0.5$ & 0.247 \\
\hline & & AM2 & $6.3 \pm 1.2$ & $6.7 \pm 1.2$ & $6.6 \pm 1.5$ & 0.773 \\
\hline
\end{tabular}

Joint angles and moments reported in the table as the average \pm standard deviation. Hip flexion, knee flexion, and ankle dorsiflexion angles are positive. Hip extension, knee extension, and ankle plantarflexion moments are positive and were normalized to body mass, height, and walking speed.

Superscripted letters indicate pairwise differences between:

a Younger and Older

b Younger and KOA

c Older and KOA 

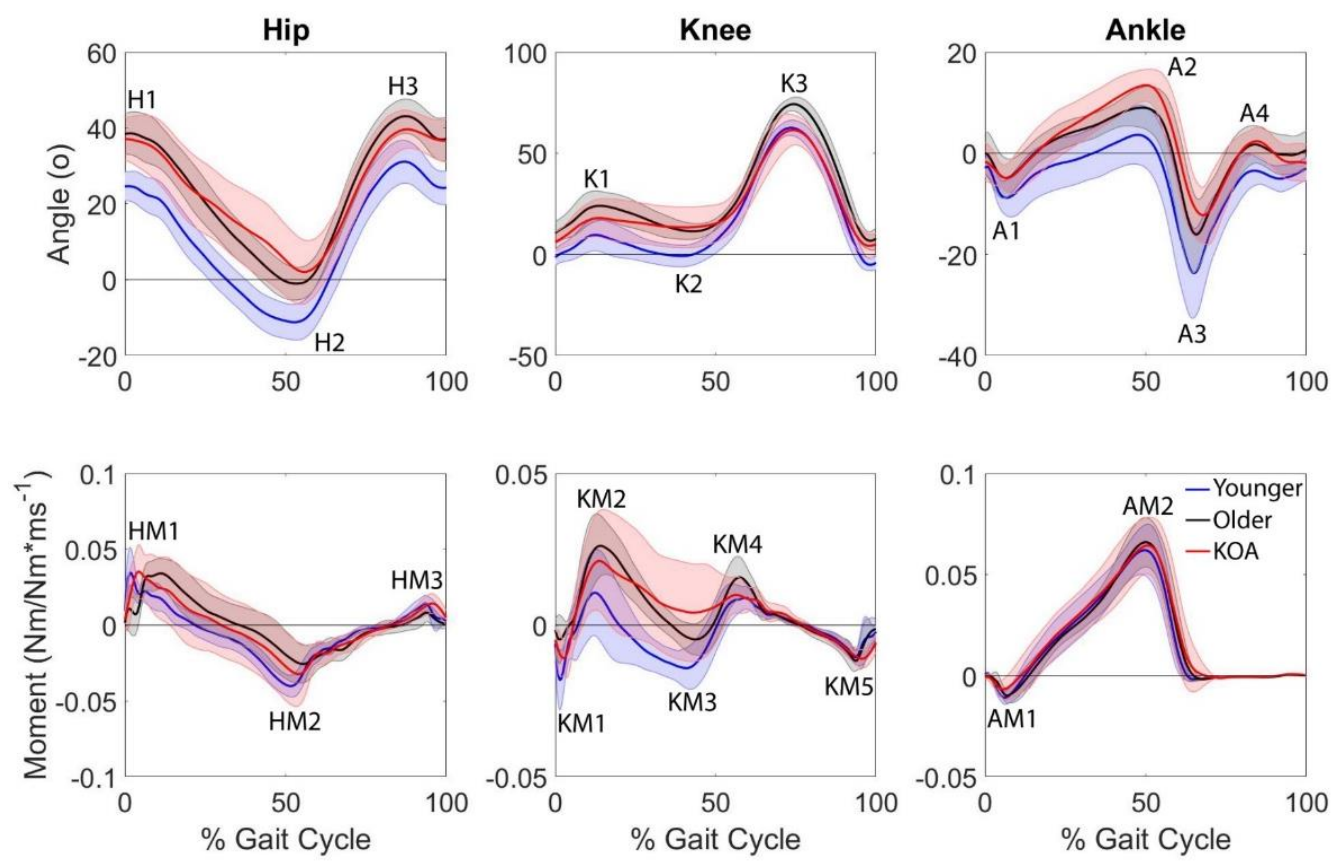

Figure 5: Population sagittal plane joint angles and joint moments (normalized to body weight, height, and gait speed). Solid lines represent population average and shaded error bars represent \pm one standard deviation. Positive values represent hip flexion, knee flexion, and ankle dorsiflexion angles and hip extension, knee extension, and ankle plantarflexion moments.

Module group kinematics (Table 4 and Figure 6) and kinetics (Table 5 and Figure 7) for each population are provided for reference. In the three module group, the older adults had a greater peak late stance knee flexion angle than the younger adults and KOA patients (K3: $p \leq 0.048)$. There were no differences in all other peak joint angles and moments between populations for the three module group $(p \geq 0.060)$. 


\section{Table 4: Peak Angles by Module Group}

\begin{tabular}{|c|c|c|c|c|c|c|c|c|c|c|c|}
\hline \multirow{3}{*}{$\begin{array}{l}\text { Module } \\
\text { Group }\end{array}$} & \multirow{3}{*}{ Population } & \multicolumn{10}{|c|}{ Angles (0) } \\
\hline & & \multicolumn{3}{|c|}{ Hip } & \multicolumn{3}{|c|}{ Knee } & \multicolumn{4}{|c|}{ Ankle } \\
\hline & & $\mathrm{H} 1$ & $\mathrm{H} 2$ & H3 & K1 & K2 & K3 & A1 & $\mathrm{A} 2$ & A3 & A4 \\
\hline \multirow{3}{*}{$\begin{array}{c}\text { Two } \\
\text { Modules }\end{array}$} & Younger $(n=0)$ & - & - & - & - & - & - & - & - & - & - \\
\hline & Older $(n=1)$ & $37.0 \pm 0.0$ & $-5.9 \pm 0.0$ & $40.0 \pm 0.0$ & $21.7 \pm 0.0$ & $5.8 \pm 0.0$ & $73.5 \pm 0.0$ & $-3.0 \pm 0.0$ & $11.4 \pm 0.0$ & $-15.5 \pm 0.0$ & $5.4 \pm 0.0$ \\
\hline & $\operatorname{KOA}(n=2)$ & $40.0 \pm 5.7$ & $2.0 \pm 11.9$ & $42.9 \pm 6.6$ & $13.7 \pm 13.5$ & $9.1 \pm 11.6$ & $66.7 \pm 1.4$ & $-11.3 \pm 4.3$ & $13.7 \pm 8.0$ & $-17.6 \pm 2.7$ & $3.2 \pm 3.7$ \\
\hline \multirow{3}{*}{$\begin{array}{c}\text { Three } \\
\text { Modules }\end{array}$} & Younger $(n=3)$ & $28.7 \pm 2.4$ & $-6.2 \pm 4.5$ & $36.2 \pm 1.0$ & $12.2 \pm 5.2$ & $0.5 \pm 1.7$ & $64.2 \pm 3.9$ & $-8.5 \pm 1.5$ & $9.3 \pm 0.8$ & $-23.7 \pm 9.0$ & $-1.7 \pm 1.6$ \\
\hline & Older $(n=5)$ & $36.5 \pm 3.3$ & $-3.2 \pm 3.4$ & $40.7 \pm 3.4$ & $24.5 \pm 8.9$ & $10.9 \pm 4.2$ & $75.6 \pm 4.5$ & $-4.6 \pm 3.6$ & $10.2 \pm 4.4$ & $-17.7 \pm 7.4$ & $3.0 \pm 3.7$ \\
\hline & $\mathrm{KOA}(\mathrm{n}=6)$ & $35.2 \pm 6.0$ & $-0.5 \pm 8.4$ & $37.9 \pm 4.6$ & $18.6 \pm 6.6$ & $11.4 \pm 8.6$ & $60.0 \pm 7.1$ & $-4.4 \pm 3.1$ & $13.7 \pm 1.8$ & $-11.9 \pm 4.4$ & $2.0 \pm 2.6$ \\
\hline \multirow{3}{*}{$\begin{array}{c}\text { Four } \\
\text { Modules }\end{array}$} & Younger $(n=4)$ & $25.2 \pm 2.6$ & $-12.6 \pm 2.8$ & $32.0 \pm 6.2$ & $9.4 \pm 12.1$ & $-4.2 \pm 7.7$ & $64.5 \pm 2.0$ & $-11.1 \pm 5.8$ & $2.0 \pm 4.7$ & $-30.2 \pm 6.1$ & $-3.2 \pm 3.7$ \\
\hline & Older $(n=3)$ & $45.0 \pm 7.4$ & $3.1 \pm 2.2$ & $47.8 \pm 3.2$ & $27.0 \pm 7.1$ & $13.6 \pm 2.4$ & $72.5 \pm 1.1$ & $-5.0 \pm 3.4$ & $10.1 \pm 3.1$ & $-18.3 \pm 12.2$ & $3.3 \pm 3.7$ \\
\hline & $\operatorname{KOA}(n=1)$ & $48.9 \pm 0.0$ & $11.5 \pm 0.0$ & $43.6 \pm 0.0$ & $34.9 \pm 0.0$ & $31.1 \pm 0.0$ & $70.1 \pm 0.0$ & $-6.5 \pm 0.0$ & $16.8 \pm 0.0$ & $-20.7 \pm 0.0$ & $5.6 \pm 0.0$ \\
\hline \multirow{3}{*}{$\begin{array}{c}\text { Five } \\
\text { Modules }\end{array}$} & Younger $(n=2)$ & $21.2 \pm 1.9$ & $-14.4 \pm 1.9$ & $27.8 \pm 1.1$ & $5.5 \pm 1.4$ & $-2.0 \pm 5.7$ & $57.3 \pm 2.7$ & $-9.1 \pm 1.5$ & $1.2 \pm 6.8$ & $-21.7 \pm 16.8$ & $-2.0 \pm 1.5$ \\
\hline & Older $(n=1)$ & $37.6 \pm 0.0$ & $-0.2 \pm 0.0$ & $45.8 \pm 0.0$ & $20.2 \pm 0.0$ & $10.8 \pm 0.0$ & $78.3 \pm 0.0$ & $-12.3 \pm 0.0$ & $4.5 \pm 0.0$ & $-18.0 \pm 0.0$ & $-1.9 \pm 0.0$ \\
\hline & $\operatorname{KOA}(n=1)$ & $36.6 \pm 0.0$ & $2.4 \pm 0.0$ & $44.8 \pm 0.0$ & $16.4 \pm 0.0$ & $10.4 \pm 0.0$ & $65.1 \pm 0.0$ & $-4.9 \pm 0.0$ & $14.5 \pm 0.0$ & $-26.8 \pm 0.0$ & $6.0 \pm 0.0$ \\
\hline \multirow{3}{*}{$\begin{array}{c}\text { Six } \\
\text { Modules }\end{array}$} & Younger $(n=1)$ & $19.1 \pm 0.0$ & $-16.6 \pm 0.0$ & $22.1 \pm 0.0$ & $14.1 \pm 0.0$ & $3.9 \pm 0.0$ & $63.1 \pm 0.0$ & $-5.5 \pm 0.0$ & $9.5 \pm 0.0$ & $-17.3 \pm 0.0$ & $1.6 \pm 0.0$ \\
\hline & Older $(n=0)$ & - & - & - & - & - & - & - & - & - & - \\
\hline & $\operatorname{KOA}(n=0)$ & - & - & - & - & - & - & - & - & - & - \\
\hline
\end{tabular}

Joint angles reported in the table as the average \pm standard deviation. Hip flexion, knee flexion, and ankle dorsiflexion are positive. 
Table 5: Peak Moments by Module Group

\begin{tabular}{|c|c|c|c|c|c|c|c|c|c|c|c|}
\hline \multirow{3}{*}{$\begin{array}{l}\text { Module } \\
\text { Group }\end{array}$} & \multirow{3}{*}{ Population } & \multicolumn{10}{|c|}{ Moments $\left(\times 10^{-2} \mathrm{Nm} / \mathrm{Nm}^{*} \mathrm{~ms}^{-1}\right)$} \\
\hline & & \multicolumn{3}{|c|}{ Hip } & \multicolumn{5}{|c|}{ Knee } & \multicolumn{2}{|c|}{ Ankle } \\
\hline & & HM1 & HM2 & HM3 & KM1 & KM2 & KM3 & KM4 & KM5 & AM1 & AM2 \\
\hline \multirow{3}{*}{$\begin{array}{c}\text { Two } \\
\text { Modules }\end{array}$} & Younger $(n=0)$ & - & - & - & - & - & - & - & - & - & - \\
\hline & Older $(n=1)$ & $2.8 \pm 0.0$ & $-3.7 \pm 0.0$ & $0.8 \pm 0.0$ & $-0.1 \pm 0.0$ & $2.6 \pm 0.0$ & $-1.0 \pm 0.0$ & $1.5 \pm 0.0$ & $-1.1 \pm 0.0$ & $-0.8 \pm 0.0$ & $7.3 \pm 0.0$ \\
\hline & $\operatorname{KOA}(n=2)$ & $3.4 \pm 1.4$ & $-2.2 \pm 0.3$ & $1.2 \pm 0.4$ & $-1.1 \pm 0.5$ & $0.6 \pm 2.4$ & $-0.7 \pm 2.7$ & $1.0 \pm 0.4$ & $-1.0 \pm 0.3$ & $-0.9 \pm 0.7$ & $5.1 \pm 0.6$ \\
\hline \multirow{3}{*}{$\begin{array}{l}\text { Three } \\
\text { Modules }\end{array}$} & Younger $(n=3)$ & $3.9 \pm 0.6$ & $-4.2 \pm 0.6$ & $1.3 \pm 0.1$ & $-2.1 \pm 0.3$ & $1.9 \pm 1.3$ & $-1.5 \pm 0.8$ & $1.1 \pm 0.3$ & $-1.3 \pm 0.2$ & $-1.1 \pm 0.1$ & $7.4 \pm 0.8$ \\
\hline & Older $(n=5)$ & $3.7 \pm 1.2$ & $-2.8 \pm 0.7$ & $1.0 \pm 0.7$ & $-0.8 \pm 0.8$ & $3.0 \pm 1.1$ & $-0.5 \pm 0.3$ & $1.7 \pm 0.5$ & $-1.3 \pm 0.3$ & $-1.1 \pm 0.4$ & $6.5 \pm 0.6$ \\
\hline & $\operatorname{KOA}(n=6)$ & $3.8 \pm 2.2$ & $-4.2 \pm 2.2$ & $1.5 \pm 0.5$ & $-1.4 \pm 0.7$ & $2.7 \pm 1.3$ & $0.3 \pm 1.3$ & $1.5 \pm 0.6$ & $-1.2 \pm 0.3$ & $-0.8 \pm 0.7$ & $7.2 \pm 1.5$ \\
\hline \multirow{3}{*}{$\begin{array}{c}\text { Four } \\
\text { Modules }\end{array}$} & Younger $(n=4)$ & $4.5 \pm 1.3$ & $-3.9 \pm 1.1$ & $1.7 \pm 0.8$ & $-2.1 \pm 1.5$ & $0.8 \pm 1.7$ & $-2.0 \pm 0.3$ & $1.1 \pm 0.6$ & $-1.1 \pm 0.4$ & $-1.3 \pm 0.2$ & $5.7 \pm 0.7$ \\
\hline & Older $(n=3)$ & $4.4 \pm 0.2$ & $-3.1 \pm 1.6$ & $1.0 \pm 0.5$ & $-0.9 \pm 0.9$ & $2.7 \pm 1.1$ & $-0.1 \pm 0.3$ & $1.7 \pm 0.9$ & $-1.3 \pm 0.6$ & $-1.0 \pm 0.5$ & $6.0 \pm 1.2$ \\
\hline & $\operatorname{KOA}(n=1)$ & $5.7 \pm 0.0$ & $-2.0 \pm 0.0$ & $0.4 \pm 0.0$ & $-1.1 \pm 0.0$ & $3.0 \pm 0.0$ & $1.0 \pm 0.0$ & $1.9 \pm 0.0$ & $-0.8 \pm 0.0$ & $-1.0 \pm 0.0$ & $6.3 \pm 0.0$ \\
\hline \multirow{3}{*}{$\begin{array}{c}\text { Five } \\
\text { Modules }\end{array}$} & Younger $(n=2)$ & $2.7 \pm 1.1$ & $-4.3 \pm 0.0$ & $1.8 \pm 0.5$ & $-1.3 \pm 0.7$ & $0.1 \pm 1.1$ & $-1.3 \pm 0.2$ & $0.8 \pm 0.3$ & $-1.3 \pm 0.4$ & $-0.7 \pm 0.2$ & $6.1 \pm 2.3$ \\
\hline & Older $(n=1)$ & $3.8 \pm 0.0$ & $-2.8 \pm 0.0$ & $0.4 \pm 0.0$ & $-0.1 \pm 0.0$ & $2.0 \pm 0.0$ & $-1.7 \pm 0.0$ & $1.9 \pm 0.0$ & $-1.6 \pm 0.0$ & $-0.9 \pm 0.0$ & $9.4 \pm 0.0$ \\
\hline & $\operatorname{KOA}(n=1)$ & $4.1 \pm 0.0$ & $-3.8 \pm 0.0$ & $2.5 \pm 0.0$ & $-1.9 \pm 0.0$ & $3.0 \pm 0.0$ & $0.0 \pm 0.0$ & $0.5 \pm 0.0$ & $-1.4 \pm 0.0$ & $-1.0 \pm 0.0$ & $6.7 \pm 0.0$ \\
\hline \multirow{3}{*}{$\begin{array}{c}\text { Six } \\
\text { Modules }\end{array}$} & Younger $(n=1)$ & $3.6 \pm 0.0$ & $-4.1 \pm 0.0$ & $1.5 \pm 0.0$ & $1.7 \pm 0.0$ & $2.4 \pm 0.0$ & $-0.6 \pm 0.0$ & $1.2 \pm 0.0$ & $-1.0 \pm 0.0$ & $-1.6 \pm 0.0$ & $6.2 \pm 0.0$ \\
\hline & Older $(n=0)$ & - & - & - & - & - & - & - & - & - & - \\
\hline & $\operatorname{KOA}(n=0)$ & - & - & - & - & - & - & - & - & - & - \\
\hline
\end{tabular}

Joint moments were normalized to body mass, height, and walking speed and are reported as the average \pm standard deviation. Hip extension, knee extension, and ankle plantarflexion are positive. 
medRxiv preprint doi: https://doi.org/10.1101/2020.05.22.20110536; this version posted June 25, 2020. The copyright holder for this preprint (which was not certified by peer review) is the author/funder, who has granted medRxiv a license to display the preprint in perpetuity. All rights reserved. No reuse allowed without permission.
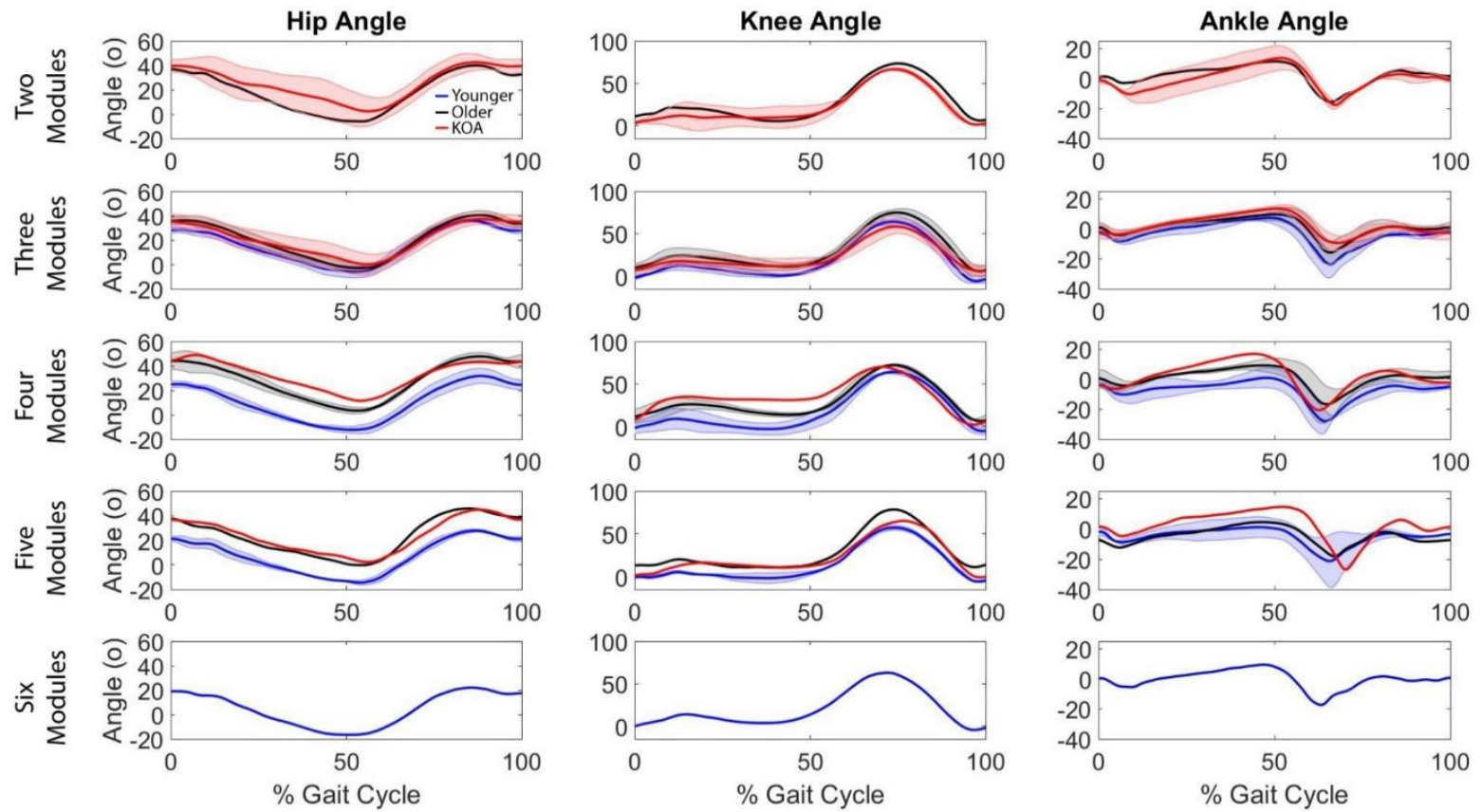

Figure 6: Module group sagittal plane joint angles. Solid lines represent module group average and shaded error bars (when appropriate) represent \pm one standard deviation for each population. Positive values represent hip flexion, knee flexion, and ankle dorsiflexion.
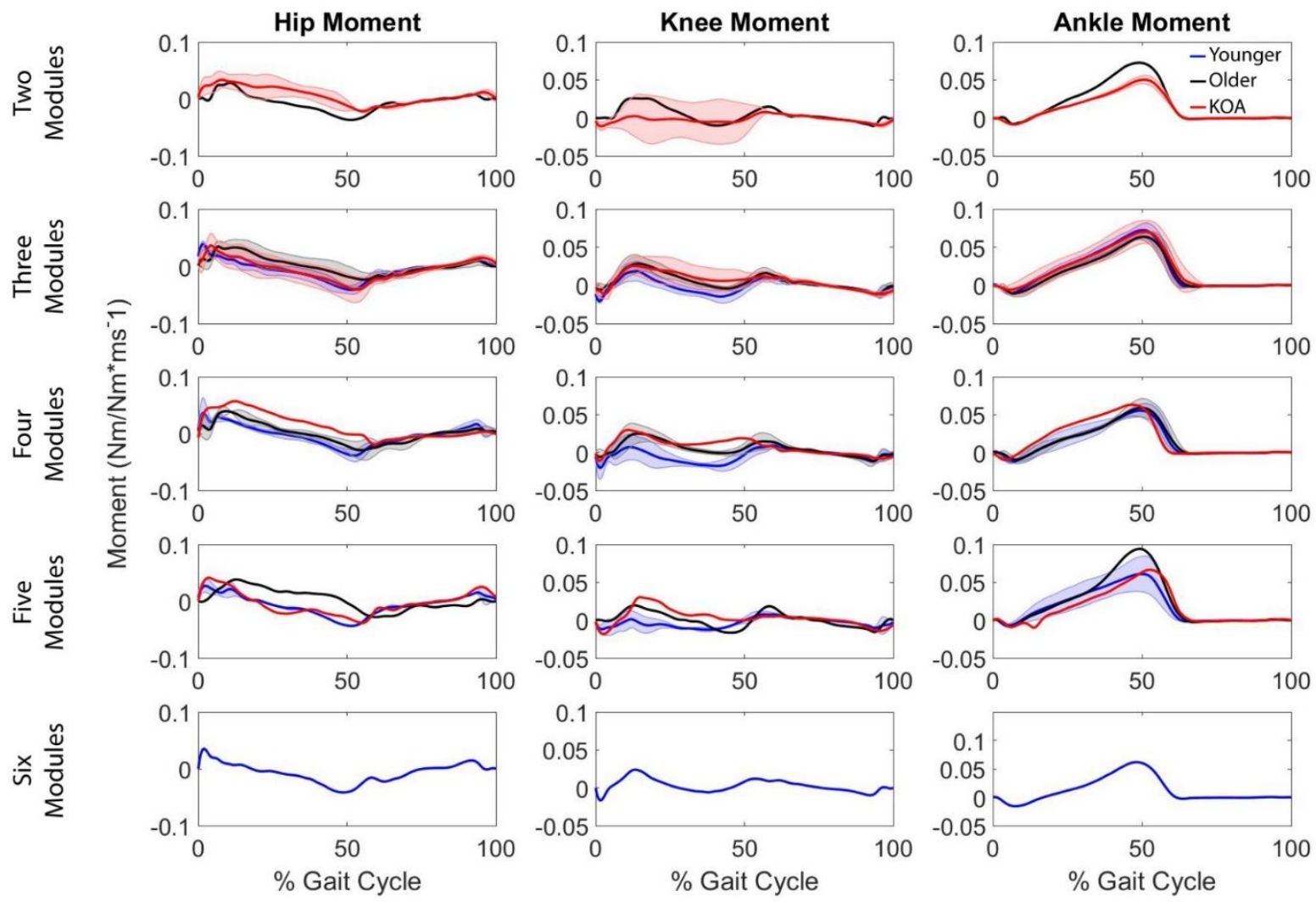

Figure 7: Module group sagittal plane joint moments (normalized to body weight, height, and gait speed). Solid lines represent module group average and shaded error bars (when appropriate) represent \pm one standard deviation for each population. Positive values represent hip extension, knee extension, and ankle plantarflexion moments. 


\section{Population Demographics and Clinical Assessments by Module Group}

Module group demographics for each population are provided for reference (Table 6). Self-selected walking speed was significantly correlated with module group when all participants were grouped together $(r=0.401, p=0.028$; Figure 8). However, for individual populations there was no signficant association between module group and self-selected walking speed (Younger: $r=0.507, p=0.135$; Older: $r=-0.119, p=0.744$;

$\mathrm{KOA}: r=0.289, p=0.418)$.

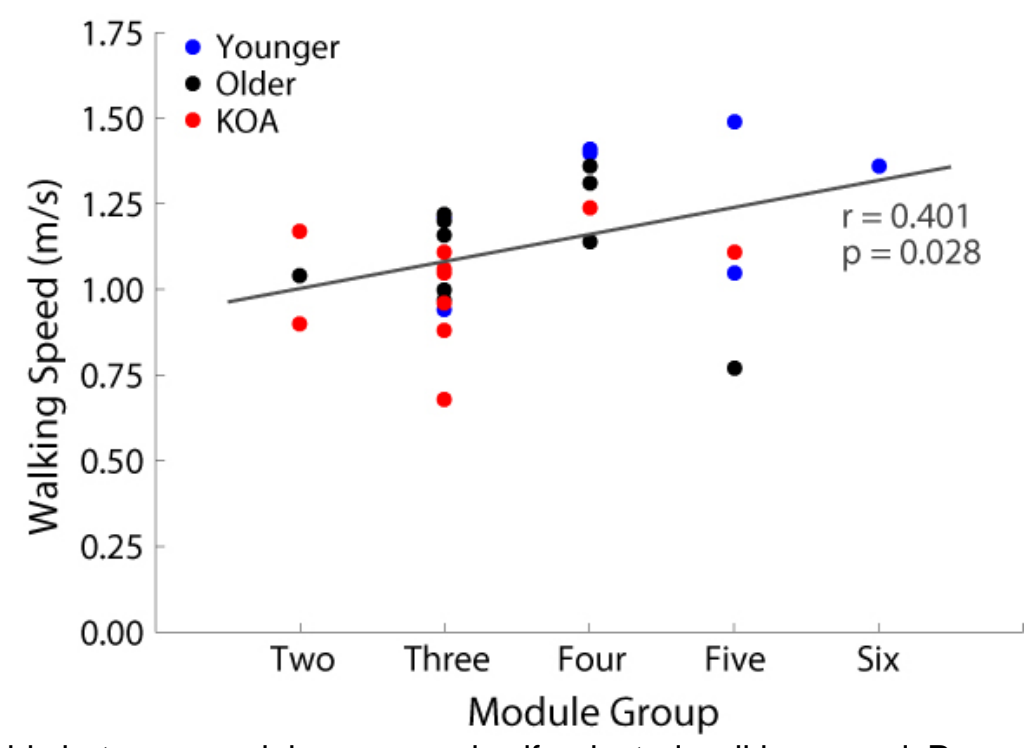

Figure 8: Relationship between module group and self-selected walking speed. Pearson correlation shown for all participants grouped together. See text for population-level Pearson correlations.

There were no significant correlations between $\mathrm{KOA}$ module group and $\mathrm{KL}$ grade ( $r=0.184, p=0.611$ ), performance-based clinical assessments (all $p \geq 0.264$ ), or KOOS scores (all $p \geq 0.630$; Table 7; Figure 9). 
Table 6: Population Demographics by Module Group

\begin{tabular}{|c|c|c|c|c|c|c|c|c|}
\hline $\begin{array}{l}\text { Module } \\
\text { Group }\end{array}$ & Population & Sex & $\begin{array}{c}\text { Age } \\
\text { (years) }\end{array}$ & Height (m) & Mass $(\mathrm{kg})$ & $\begin{array}{c}\mathrm{BMl} \\
\left(\mathrm{kg} / \mathrm{m}^{2}\right)\end{array}$ & $\begin{array}{l}\text { Walking } \\
\text { Speed } \\
(\mathrm{m} / \mathrm{s})\end{array}$ & $\begin{array}{c}\text { Normalized } \\
\text { Stride } \\
\text { Length }\end{array}$ \\
\hline \multirow{3}{*}{$\begin{array}{c}\text { Two } \\
\text { Modules }\end{array}$} & Younger $(n=0)$ & - & - & - & - & - & - & - \\
\hline & Older $(n=1)$ & $1 \mathrm{M}, \mathrm{OF}$ & $68.0 \pm 0.0$ & $1.80 \pm 0.00$ & $88.2 \pm 0.0$ & $27.1 \pm 0.0$ & $1.04 \pm 0.00$ & $1.34 \pm 0.00$ \\
\hline & $\operatorname{KOA}(n=2)$ & $0 \mathrm{M}, 2 \mathrm{~F}$ & $65.5 \pm 0.7$ & $1.67 \pm 0.10$ & $99.0 \pm 0.3$ & $35.7 \pm 4.1$ & $1.04 \pm 0.19$ & $1.62 \pm 0.27$ \\
\hline \multirow{3}{*}{$\begin{array}{l}\text { Three } \\
\text { Modules }\end{array}$} & Younger $(n=3)$ & $1 \mathrm{M}, 2 \mathrm{~F}$ & $22.7 \pm 3.1$ & $1.72 \pm 0.09$ & $64.1 \pm 3.7$ & $21.7 \pm 2.4$ & $1.07 \pm 0.14$ & $1.49 \pm 0.13$ \\
\hline & Older $(n=5)$ & $1 \mathrm{M}, 4 \mathrm{~F}$ & $63.8 \pm 3.6$ & $1.65 \pm 0.04$ & $64.6 \pm 7.0$ & $23.5 \pm 1.9$ & $1.11 \pm 0.12$ & $1.52 \pm 0.13$ \\
\hline & $\operatorname{KOA}(n=6)$ & $2 \mathrm{M}, 4 \mathrm{~F}$ & $63.2 \pm 4.3$ & $1.68 \pm 0.10$ & $86.4 \pm 7.0$ & $30.9 \pm 4.0$ & $0.96 \pm 0.16$ & $1.40 \pm 0.15$ \\
\hline \multirow{3}{*}{$\begin{array}{l}\text { Four } \\
\text { Modules }\end{array}$} & Younger $(n=4)$ & $3 \mathrm{M}, 1 \mathrm{~F}$ & $24.8 \pm 3.6$ & $1.74 \pm 0.05$ & $70.1 \pm 11.9$ & $23.1 \pm 3.4$ & $1.32 \pm 0.10$ & $1.75 \pm 0.12$ \\
\hline & Older $(n=3)$ & $2 \mathrm{M}, 1 \mathrm{~F}$ & $62.0 \pm 3.5$ & $1.75 \pm 0.06$ & $81.4 \pm 15.7$ & $26.5 \pm 3.3$ & $1.27 \pm 0.12$ & $1.61 \pm 0.17$ \\
\hline & $\operatorname{KOA}(n=1)$ & $1 \mathrm{M}, \mathrm{OF}$ & $63.0 \pm 0.0$ & $1.65 \pm 0.00$ & $87.9 \pm 0.0$ & $32.2 \pm 0.0$ & $1.24 \pm 0.00$ & $1.52 \pm 0.12$ \\
\hline \multirow{3}{*}{$\begin{array}{c}\text { Five } \\
\text { Modules }\end{array}$} & Younger $(n=2)$ & $1 \mathrm{M}, 1 \mathrm{~F}$ & $21.0 \pm 0.0$ & $1.84 \pm 0.03$ & $80.4 \pm 8.2$ & $23.7 \pm 1.7$ & $1.27 \pm 0.31$ & $1.55 \pm 0.18$ \\
\hline & Older $(n=1)$ & $0 \mathrm{M}, 1 \mathrm{~F}$ & $62.0 \pm 0.0$ & $1.57 \pm 0.00$ & $59.4 \pm 0.0$ & $24.0 \pm 0.0$ & $0.77 \pm 0.00$ & $1.26 \pm 0.00$ \\
\hline & $\operatorname{KOA}(n=1)$ & $0 \mathrm{M}, 1 \mathrm{~F}$ & $62.0 \pm 0.0$ & $1.66 \pm 0.00$ & $92.3 \pm 0.0$ & $33.3 \pm 0.0$ & $1.11 \pm 0.00$ & $1.60 \pm 0.00$ \\
\hline \multirow{3}{*}{$\begin{array}{c}\text { Six } \\
\text { Modules }\end{array}$} & Younger $(n=1)$ & $0 \mathrm{M}, 1 \mathrm{~F}$ & $26.0 \pm 0.0$ & $1.72 \pm 0.00$ & $79.0 \pm 0.0$ & $26.7 \pm 0.0$ & $1.36 \pm 0.00$ & $1.73 \pm 0.00$ \\
\hline & Older $(n=0)$ & - & - & - & - & - & - & - \\
\hline & $\operatorname{KOA}(n=0)$ & - & - & - & - & - & - & - \\
\hline
\end{tabular}


Table 7: Knee Osteoarthritis Clinical Assessments by Module Group

\begin{tabular}{c|c|ccc|cccc}
\hline \multirow{2}{*}{ Module Group } & \multirow{2}{*}{ KL Grade } & \multicolumn{3}{|c|}{ Performance-Based Outcomes } & \multicolumn{4}{c}{ KOOS Scores } \\
\cline { 3 - 8 } & & 6 MW $(\mathrm{m})$ & SCT $(\mathrm{s})$ & TUG $(\mathrm{s})$ & Pain & Symptoms & ADL & QOL \\
\hline Two Modules $(\mathrm{n}=2)$ & $3.0 \pm 0.0$ & $394.7 \pm 131.6$ & $31.9 \pm 19.5$ & $10.5 \pm 3.2$ & $54.0 \pm 9.9$ & $61.0 \pm 9.9$ & $62.0 \pm 0.0$ & $41.0 \pm 4.3$ \\
Three Modules $(\mathrm{n}=6)$ & $3.3 \pm 0.5$ & $390.5 \pm 59.7$ & $26.7 \pm 16.0$ & $10.3 \pm 2.4$ & $54.5 \pm 29.3$ & $53.5 \pm 26.7$ & $61.0 \pm 24.1$ & $30.5 \pm 31.6$ \\
Four Modules $(\mathrm{n}=1)$ & $4.0 \pm 0.0$ & $515.6 \pm 0.0$ & $16.6 \pm 0.0$ & $9.0 \pm 0.0$ & $53.0 \pm 0.0$ & $50.0 \pm 0.0$ & $65.0 \pm 0.0$ & $31.0 \pm 0.0$ \\
Five Modules $(\mathrm{n}=1)$ & $3.0 \pm 0.0$ & $459.0 \pm 0.0$ & $23.5 \pm 0.0$ & $9.9 \pm 0.0$ & $61.0 \pm 0.0$ & $50.0 \pm 0.0$ & $56.0 \pm 0.0$ & $25.0 \pm 0.0$ \\
\hline
\end{tabular}
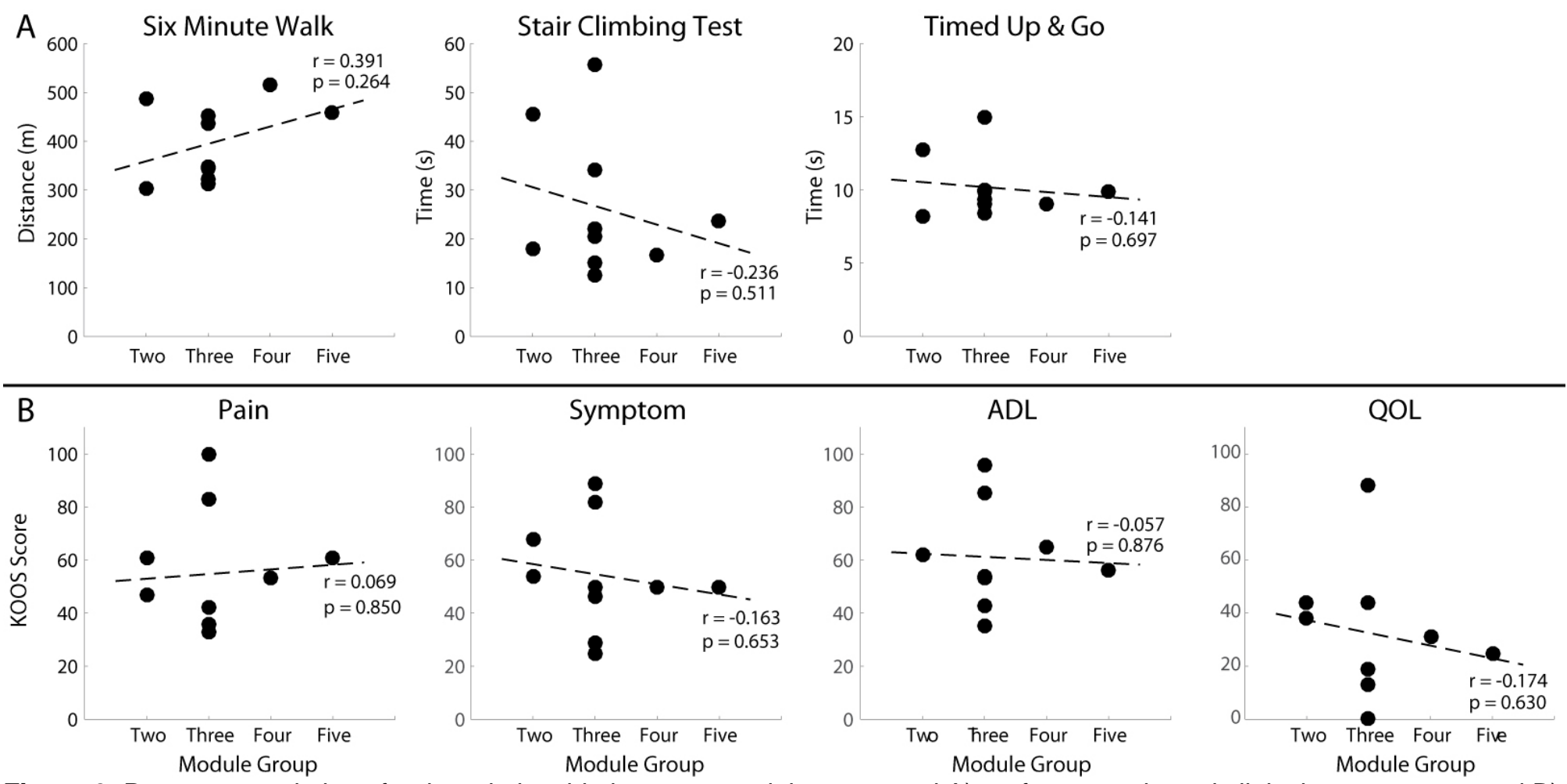

Figure 9: Pearson correlations for the relationship between module group and A) performance-based clinical assessments and B) KOOS subscale scores. 
medRxiv preprint doi: https://doi.org/10.1101/2020.05.22.20110536; this version posted June 25, 2020. The copyright holder for this preprint (which was not certified by peer review) is the author/funder, who has granted medRxiv a license to display the preprint in perpetuity.

\section{DISCUSSION}

This pilot study aimed to determine if age and KOA alter the modular control of walking. The experimental activation patterns of all subjects were able to be reduced to a modular organization. Thus, the findings of this study contribute to the evidence for a low-dimensional organization of the neural control of muscles during gait across age groups and in the presence of pathology. On average, there was a trend toward a reduced number of modules required to adequately reconstruct the experimental activations from younger adults to older adults and KOA patients. However, this trend was not statistically significant and further research with additional participants is necessary to determine if age and KOA lead to fewer number of modules. Still, the greater minimum VAF captured by fewer modules in the KOA patients compared to the healthy adults is suggestive of decreased modular control complexity.

There was a relatively wide range of the number of required modules in each population in this study (younger: $3-6$, older: $2-5, \mathrm{KOA}: 2-5$ ). However, previous studies have reported similar ranges in module number (2-5) for walking in healthy younger and older adults and patient populations (e.g., Allen et al. 2019; Allen and Franz 2018; Clark et al. 2010b). In addition, it has not been determined how movement history (e.g., previous training or injury) may influence module control complexity and thus remains an important area for future research. Given that the muscle set collected in this study is comprised of three major muscle groups (the quadriceps, hamstrings, and plantarflexors), three modules may be sufficient for independent control of these muscle groups while additional modules may suggest greater flexibility in an individual's control strategy. However, these muscle groups include both uniarticular and biarticular muscles; thus, 
medRxiv preprint doi: https://doi.org/10.1101/2020.05.22.20110536; this version posted June 25, 2020. The copyright holder for this preprint (which was not certified by peer review) is the author/funder, who has granted medRxiv a license to display the preprint in perpetuity.

All rights reserved. No reuse allowed without permission.

individual muscles may act independently of other muscles in the group, which could result in a greater number of modules.

Within the three module group, there were no significant differences in module timing or module composition (as measured by $\mathrm{W}_{\text {sum }}$ ) between the healthy younger and older adults, which suggests the nervous system may be capable of preserving modular control with unimpaired aging. Still, though $\mathrm{W}_{\text {sum }}$ did not differ between unimpaired age groups, the older adults had more muscles significantly associated with the PF and HAMS modules than the younger adults which may indicate a mild increase in muscle co-activity with age. It is important to note that there was no statistically significant difference in walking speed between the younger and older adults in this study, which suggests the older adults in this study had a relatively high level of function that was not impaired by the increased muscle co-activity. Although consistent modular organization has been observed across walking speeds in healthy younger and older adults (Clark et al. 2010; Ivanenko et al. 2004), module group was significantly associated with self-selected walking speed in this study and previous studies have reported an association between slower walking speeds and altered modular organization in patient populations (Clark et al. 2010; Hayes et al. 2014). Therefore, future studies should investigate modular control in older adults with slower self-selected walking speeds to clarify the relationship between age-related changes in motor control and functional performance.

The KOA patients in the three module group exhibited altered module timing and composition compared to the unimpaired younger and older adults, which suggests these differences in modular control may be disease-related. Within the three module group, the greater number of muscles $\left(\mathrm{W}_{\text {musc }}\right)$ significantly associated with the QUAD and PF 
medRxiv preprint doi: https://doi.org/10.1101/2020.05.22.20110536; this version posted June 25, 2020. The copyright holder for this preprint (which was not certified by peer review) is the author/funder, who has granted medRxiv a license to display the preprint in perpetuity.

All rights reserved. No reuse allowed without permission.

modules in the KOA patients indicates a loss of flexibility to individually activate specific muscles or muscle groups and led to the KOA patients' increased co-activity in these modules, as measured by $\mathrm{W}_{\text {sum. }}$ In the QUAD module, the KOA patients' increased $\mathrm{W}_{\text {sum }}$ was due to the added contributions from the biceps femoris and lateral gastrocnemius $\left(\right.$ KOA QUAD $W_{\text {musc }}=6$ while younger and older adult QUAD $W_{\text {musc }}=4$; see Table 2$)$, which is suggestive of increased co-contraction on the lateral side of the knee during early stance when the QUAD module is primarily active. Moreover, though the QUAD module was primarily active during weight acceptance in the unimpaired adults, the KOA patients exhibited elevated QUAD module activation through early midstance. Interestingly, although the younger and older adults had the same number of muscles associated with the QUAD module, the KOA patients' QUAD W sum was only significantly greater than the younger, but not the older, adults. The absence of significant differences between the

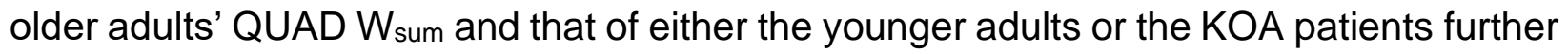
suggests that there is a mild increase in muscle co-activity with age and that this increased co-activity may be exacerbated in the presence of KOA.

In the PF module, the KOA patients' increased $\mathrm{W}_{\text {sum }}$ was due to the added contributions from the medial vasti and hamstrings $\left(\mathrm{KOA} P F \mathrm{~W}_{\text {musc }}=6\right.$ compared to $\mathrm{W}_{\text {musc }}$ $=4$ and $W_{\text {musc }}=5$ for the younger and older adults, respectively; see Table 2), which is suggestive of increased co-contraction on the medial side of the knee during late stance when the PF module is primarily active. The lateralized increased muscle co-contraction about the knee observed in KOA patients during early (QUAD module) and late (PF module) stance may be suggestive of a motor control strategy to modulate mediolateral knee stability during the stance phase. However, a previous study demonstrated that 
medRxiv preprint doi: https://doi.org/10.1101/2020.05.22.20110536; this version posted June 25, 2020. The copyright holder for this preprint (which was not certified by peer review) is the author/funder, who has granted medRxiv a license to display the preprint in perpetuity.

All rights reserved. No reuse allowed without permission.

decreased co-contraction following neuromuscular retraining was associated with decreased knee pain, which the authors suggested supported the idea that increased muscle co-contraction may be a maladaptive control strategy in KOA (Preece et al. 2016). Thus, KOA-related maladaptive changes may contribute to impaired module composition in KOA patients.

There were no differences in the HAMS module $\mathrm{W}_{\text {sum }}$ between populations despite different $W_{\text {musc }}$ values for each population. Though the KOA patients' lateral gastrocnemius was significantly associated with the HAMS module, this added weight was low on average and their biceps femoris weight was, on average, lower than that of the unimpaired adults leading to a similar average $W_{\text {sum }}$ as the young adults (Figure 4 ). Similarly, in the older adults the added weights of the medial vasti and gastrocnemius were relatively low. The resulting absence of differences in HAMS $\mathrm{W}_{\text {sum }}$ between populations suggest the control of the HAMS module was not significantly affected by age or disease.

At the population level, the peak joint angles and moments of the healthy older adults and KOA patients generally differed from those of the younger adults but not from each other. Although there were no significant differences in the number of required modules between populations, on an individual subject basis module number is an integer. Thus, one could interpret the results of this study as, on average, the younger adults having 4 modules while the healthy older adults and KOA patients had 3 modules. It may be that the loss of a module, on average, resulted in the observed differences in joint biomechanics. However, given the small cohort included in this pilot study, we are unable to conclude a direct relationship between a reduced number of modules and 
medRxiv preprint doi: https://doi.org/10.1101/2020.05.22.20110536; this version posted June 25, 2020. The copyright holder for this preprint (which was not certified by peer review) is the author/funder, who has granted medRxiv a license to display the preprint in perpetuity.

All rights reserved. No reuse allowed without permission.

altered biomechanics between the younger adults and the older adults with and without KOA.

Still, the relationship between module composition and joint mechanics can be examined between populations for individuals with the same number of modules. Although there were no differences in peak joint moments at the module group level, a trend towards a smaller peak knee flexion moment during midstance (KM3) in the three module group KOA patients compared to the younger adults was observed $(p=0.060)$. The three module group KOA patients' average KM3 was positive, indicating that they continued to produce a knee extension moment throughout midstance. This knee extension moment during midstance corresponded to the KOA patients' greater area under the curve during early midstance in the QUAD module, which would act to increase the contribution to the knee extension moment. The KOA patients' increased $\mathrm{W}_{\text {sum }}$ in the QUAD module compared to the younger adults was due to contributions from biceps femoris and lateral gastrocnemius. During mid- to late stance, the gastrocnemius contributes to knee extension (Neptune et al. 2004) and therefore may have also contributed to the KOA patients' increased midstance knee extension moment. Future work with a larger cohort could help clarify this potential relationship between a midstance peak knee extension moment and altered QUAD module activation timing and composition in individuals with KOA.

The altered neuromuscular control strategy identified in the KOA patients in this study suggests that the reduced modular control complexity observed in individuals who had undergone a TKA (Ardestani et al. 2017) may have been present prior to surgery. Thus, replacement of the joint structure alone may not be sufficient to improve locomotor 
medRxiv preprint doi: https://doi.org/10.1101/2020.05.22.20110536; this version posted June 25, 2020. The copyright holder for this preprint (which was not certified by peer review) is the author/funder, who has granted medRxiv a license to display the preprint in perpetuity.

All rights reserved. No reuse allowed without permission.

performance in individuals with end-stage KOA. However, additional research is required to determine if pre-operative modular control is associated with post-operative modular control. Retraining the neuromuscular control strategy may be required to achieve improvements in walking speed and coordination in individuals with KOA or following a TKA. Gait retraining has been shown to increase the number of modules and improve the quality of the modular organization and timing in individuals with post-stroke hemiparesis (Routson et al. 2013) and reduce co-contraction and knee pain in patients with KOA (Preece et al. 2016). Therefore, rehabilitation protocols aimed at appropriately timed muscle activity may be necessary to restore independent activation of these muscle groups in patients following a TKA.

In contrast to previous studies which have reported associations between modular organization and functional performance in impaired populations (Ardestani et al. 2017; Clark et al. 2010), the number of modules required to reconstruct the EMG of the KOA patients was not associated with differences in disease severity, self-reported function, or performance on clinical functional assessments. However, a limitation of this pilot study is the small sample size within each module group. A larger study with a sufficient sample size in each module group would be necessary to determine if differences in modular control complexity are associated with differences in measured or self-reported function in KOA patients. Furthermore, EMG from a single gait cycle was used in the NMF extraction of muscle modules for each participant. Although previous research suggests that the inclusion of EMG from 20 gait cycles in the NMF analysis provides the highest quality of muscle activation reconstruction (Oliveira et al. 2014), the authors of this previous study also stated that the number of gait cycles used in the analysis did not 
medRxiv preprint doi: https://doi.org/10.1101/2020.05.22.20110536; this version posted June 25, 2020. The copyright holder for this preprint (which was not certified by peer review) is the author/funder, who has granted medRxiv a license to display the preprint in perpetuity.

All rights reserved. No reuse allowed without permission.

impact the estimated number of modules and had a small effect on the extracted modules. Although the inclusion of EMG from additional gait cycles would be ideal, we visually inspected the quality of the EMG for all muscles in all subjects and are therefore confident in the modules extracted in this pilot study. However, future studies in these populations would help confirm these findings. In addition, only EMG from the involved limb of the KOA patients was included in this pilot study. While symmetry is a reasonable assumption in healthy adults, KOA commonly affects one knee more than the other. There may be differences in modular control between the involved limb and the contralateral limb which could provide insight into the relationship between clinical scores and motor control complexity.

In conclusion, this study revealed alterations in the modular control of walking in the presence of KOA. Though modular organization was similar between healthy age groups within the same module group, the KOA patients exhibited decreased module complexity and impaired module composition characterized by increased co-activity of all three major muscle groups crossing the knee: the quadriceps, hamstrings, and plantarflexors. The findings of this pilot study suggest a change in underlying neural control strategy associated with the presence of KOA. Future work is needed to clarify the potential relationship between KOA-related changes in modular control strategy and functional outcomes.

\section{ACKNOWLEDGEMENTS}

The authors thank Dr. Jackie Lewis and Dr. Greg Freisinger for their assistance with data collection. This research was supported by the National Science Foundation Graduate 
medRxiv preprint doi: https://doi.org/10.1101/2020.05.22.20110536; this version posted June 25, 2020. The copyright holder for this preprint (which was not certified by peer review) is the author/funder, who has granted medRxiv a license to display the preprint in perpetuity. All rights reserved. No reuse allowed without permission.

Research Fellowship Program under Grant Nos. DGE-1343012 (SAS) and DGE-0822215 (EJC), a fellowship from The Ohio State University (RRK), and by Grant Number R01AR056700 from the National Institute of Arthritis and Musculoskeletal and Skin Diseases. The content is solely the responsibility of the authors and does not necessarily represent the official views of the National Institute of Arthritis and Musculoskeletal and Skin Diseases nor the National Institutes of Health.

\section{CONFLICT OF INTEREST STATEMENT}

None of the authors have a conflict of interest regarding the contents of this manuscript. 
medRxiv preprint doi: https://doi.org/10.1101/2020.05.22.20110536; this version posted June 25, 2020. The copyright holder for this preprint (which was not certified by peer review) is the author/funder, who has granted medRxiv a license to display the preprint in perpetuity.

\section{REFERENCES}

Allen JL, Franz $\mathbf{J}$. The motor repertoire of older adult fallers may constrain their response to balance perturbations. J Neurophysiol jn.00302.2018, 2018.

Allen JL, Kesar TM, Ting LH. Motor module generalization across balance and walking is impaired after stroke. J Neurophysiol 122: 277-289, 2019.

Allen JL, Neptune RR. Three-dimensional modular control of human walking. $J$ Biomech 45: 2157-2163, 2012.

Andriacchi TP, Alexander EJ, Toney MK, Dyrby C, Sum J. A point cluster method for in vivo motion analysis: applied to a study of knee kinematics. J Biomech Eng 120: 7439, 1998.

Ardestani MM, Malloy P, Nam D, Rosenberg AG, Wimmer MA. TKA patients with unsatisfying knee function show changes in neuromotor synergy pattern but not joint biomechanics. J Electromyogr Kinesiol 37: 90-100, 2017.

Astephen JL, Deluzio KJ, Caldwell GE, Dunbar MJ. Biomechanical changes at the hip, knee, and ankle joints during gait are associated with knee osteoarthritis severity. $J$ Orthop Res , 2008a.

Astephen JL, Deluzio KJ, Caldwell GE, Dunbar MJ, Hubley-Kozey CL. Gait and neuromuscular pattern changes are associated with differences in knee osteoarthritis severity levels. J Biomech 41: 868-876, 2008b.

Cheung VCK, Turolla A, Agostini M, Silvoni S, Bennis C, Kasi P, Paganoni S, Bonato P, Bizzi E. Muscle synergy patterns as physiological markers of motor cortical damage. Proc Natl Acad Sci 109: 14652-14656, 2012.

Childs JD, Sparto PJ, Fitzgerald GK, Bizzini M, Irrgang JJ. Alterations in lower 
medRxiv preprint doi: https://doi.org/10.1101/2020.05.22.20110536; this version posted June 25, 2020. The copyright holder for this preprint (which was not certified by peer review) is the author/funder, who has granted medRxiv a license to display the preprint in perpetuity.

All rights reserved. No reuse allowed without permission.

extremity movement and muscle activation patterns in individuals with knee osteoarthritis. Clin Biomech 19: 44-49, 2004.

Clark DJ, Patten C, Reid KF, Carabello RJ, Phillips EM, Fielding RA. Muscle Performance and Physical Function Are Associated With Voluntary Rate of Neuromuscular Activation in Older Adults. Journals Gerontol Ser A Biol Sci Med Sci 66A: 115-121, 2011.

Clark DJ, Pojednic RM, Reid KF, Patten C, Pasha EP, Phillips EM, Fielding RA. Longitudinal Decline of Neuromuscular Activation and Power in Healthy Older Adults. Journals Gerontol Ser A Biol Sci Med Sci 68: 1419-1425, 2013.

Clark DJ, Ting LH, Zajac FE, Neptune RR, Kautz SA. Merging of Healthy Motor Modules Predicts Reduced Locomotor Performance and Muscle Coordination Complexity Post-Stroke. J Neurophysiol 103: 844-857, 2010.

Davis BL, Vaughan CL. Phasic behavior of EMG signals during gait: Use of multivariate statistics. J Electromyogr Kinesiol 3: 51-60, 1993.

Dobson F, Hinman RS, Roos EM, Abbott JH, Stratford P, Davis AM, Buchbinder R, Snyder-Mackler L, Henrotin Y, Thumboo J, Hansen P, Bennell KL. OARSI recommended performance-based tests to assess physical function in people diagnosed with hip or knee osteoarthritis. Osteoarthr Cartil 21: 1042-1052, 2013.

Enright PL. The six-minute walk test. [Online]. Respir Care 48: 783-5, 2003.

Freisinger GM, Hutter EE, Lewis J, Granger JF, Glassman AH, Beal MD, Pan X, Schmitt LC, Siston RA, Chaudhari AMW. Relationships between varus-valgus laxity of the severely osteoarthritic knee and gait, instability, clinical performance, and function. J Orthop Res 35: 1644-1652, 2017. 
medRxiv preprint doi: https://doi.org/10.1101/2020.05.22.20110536; this version posted June 25, 2020. The copyright holder for this preprint (which was not certified by peer review) is the author/funder, who has granted medRxiv a license to display the preprint in perpetuity.

Guccione A, Felson D, Anderson JJ, Anthony JM, Zhang Y, Wilson PWF, Kellyhayes M, Wolf PA, Kreger BE, Kannel WB. The effects of specific medical conditions on the functional limitations of elders in the Framingham Study. Am J Public Heal 84: 351-358, 1993.

Hayes HB, Chvatal SA, French MA, Ting LH, Trumbower RD. Neuromuscular constraints on muscle coordination during overground walking in persons with chronic incomplete spinal cord injury. Clin Neurophysiol 125: 2024-2035, 2014.

Hubley-Kozey C, Deluzio K, Dunbar M. Muscle co-activation patterns during walking in those with severe knee osteoarthritis. Clin Biomech 23: 71-80, 2008.

Hubley-Kozey CL, Deluzio KJ, Landry SC, McNutt JS, Stanish WD. Neuromuscular alterations during walking in persons with moderate knee osteoarthritis. $J$ Electromyogr Kinesiol 16: 365-378, 2006.

Ivanenko YP, Poppele RE, Lacquaniti F. Five basic muscle activation patterns account for muscle activity during human locomotion. J Physiol 556: 267-282, 2004. Jamison ST, Pan X, Chaudhari AMW. Knee moments during run-to-cut maneuvers are associated with lateral trunk positioning. J Biomech 45: 1881-1885, 2012.

Judge JO, Davis RB, Ounpuu S. Step Length Reductions in Advanced Age The Role of Ankle and Hip Kinetics. J Gerontol Med Sci 51: 3-3, 1996.

Kellgren JH, Lawrence JS. Radiological Assessment of Osteo-Arthrosis. Ann Rheum Dis 16: 494-502, 1957.

Kerrigan DC, Todd MK, Della Croce U, Lipsitz LA, Collins JJ. Biomechanical gait alterations independent of speed in the healthy elderly: Evidence for specific limiting impairments. Arch Phys Med Rehabil 79: 317-322, 1998. 
medRxiv preprint doi: https://doi.org/10.1101/2020.05.22.20110536; this version posted June 25, 2020. The copyright holder for this preprint (which was not certified by peer review) is the author/funder, who has granted medRxiv a license to display the preprint in perpetuity. All rights reserved. No reuse allowed without permission.

Lee DD, Seung HS. Learning the parts of objects by non-negative matrix factorization. Nature 401: 788-791, 1999.

Lewek MD, Rudolph KS, Snyder-Mackler L. Control of frontal plane knee laxity during gait in patients with medial compartment knee osteoarthritis. Osteoarthr Cartil 12: 745$751,2004$.

van Melick N, Meddeler BM, Hoogeboom TJ, Nijhuis-van der Sanden MWG, van Cingel REH. How to determine leg dominance: The agreement between self-reported and observed performance in healthy adults. PLoS One 12, 2017.

Miller ME, Rejeski WJ, Reboussin BA, Ten Have TR, Ettinger WH. Physical activity, functional limitations, and disability in older adults. J Am Geriatr Soc 48: 1264-1272, 2000.

Monaco V, Ghionzoli A, Micera S. Age-Related Modifications of Muscle Synergies and Spinal Cord Activity During Locomotion. J Neurophysiol 104: 2092-2102, 2010.

Musich S, Wang SS, Ruiz J, Hawkins K, Wicker E. The impact of mobility limitations on health outcomes among older adults. Geriatr Nurs (Minneap) 39: 162-169, 2018. Neptune RR, Clark DJ, Kautz SA. Modular control of human walking: A simulation study. J Biomech 42: 1282-1287, 2009.

Neptune RR, Zajac FE, Kautz SA. Muscle force redistributes segmental power for body progression during walking. Gait Posture 19: 194-205, 2004.

Oliveira AS, Gizzi L, Farina D, Kersting UG. Motor modules of human locomotion: influence of EMG averaging, concatenation, and number of step cycles. Front Hum Neurosci 8: 1-9, 2014.

Oliveira AS, Silva PB, Lund ME, Kersting UG, Farina D. Fast changes in direction 
medRxiv preprint doi: https://doi.org/10.1101/2020.05.22.20110536; this version posted June 25, 2020. The copyright holder for this preprint (which was not certified by peer review) is the author/funder, who has granted medRxiv a license to display the preprint in perpetuity.

All rights reserved. No reuse allowed without permission.

during human locomotion are executed by impulsive activation of motor modules.

Neuroscience 228: 283-293, 2013.

Patla AE. Some characteristics of EMG patterns during locomotion: Implications for the locomotor control process. J Mot Behav 17: 443-461, 1985.

Pendergast DR, Fisher NM, Calkins E. Cardiovascular, Neuromuscular, and Metabolic Alterations With Age Leading to Frailty. Journals Gerontol 48: 61-67, 1993.

Preece SJ, Jones RK, Brown CA, Cacciatore TW, Jones AKP. Reductions in cocontraction following neuromuscular re-education in people with knee osteoarthritis. BMC Musculoskelet Disord 17: 1-12, 2016.

Rejeski WJ, Ettinger WH, Schumaker S, James P, Burns R, Elam JT. Assessing performance-related disability in patients with knee osteoarthritis. Osteoarthr Cartil 3: 157-167, 1995.

Roh J, Rymer WZ, Perreault EJ, Yoo SB, Beer RF. Alterations in upper limb muscle synergy structure in chronic stroke survivors. J Neurophysiol 109: 768-781, 2013.

Roos EM, Roos HP, Lohmander LS, Ekdahl C, Beynnon BD. Knee Injury and Osteoarthritis Outcome Score (KOOS)_Development of a Self-Administered Outcome Measure. J Orthop Sport Phys Ther 28: 88-96, 1998.

Routson RL, Clark DJ, Bowden MG, Kautz SA, Neptune RR. The influence of locomotor rehabilitation on module quality and post-stroke hemiparetic walking performance. Gait Posture , 2013.

Rutherford DJ, Hubley-Kozey CL, Stanish WD. Changes in knee joint muscle activation patterns during walking associated with increased structural severity in knee osteoarthritis. J Electromyogr Kinesiol 23: 704-711, 2013. 
medRxiv preprint doi: https://doi.org/10.1101/2020.05.22.20110536; this version posted June 25, 2020. The copyright holder for this preprint (which was not certified by peer review) is the author/funder, who has granted medRxiv a license to display the preprint in perpetuity. All rights reserved. No reuse allowed without permission.

Schmitz A, Silder A, Heiderscheit B, Mahoney J, Thelen DG. Differences in lowerextremity muscular activation during walking between healthy older and young adults. $J$ Electromyogr Kinesiol 19: 1085-1091, 2009.

Steele KM, Rozumalski A, Schwartz MH. Muscle synergies and complexity of neuromuscular control during gait in cerebral palsy. Dev Med Child Neurol 57: 11761182, 2015.

Sugiura H, Demura S. Effects of mild and severe knee joint pain on various activities of daily living in the female elderly. Pain Res Treat 2013, 2013.

Tang L, Chen X, Cao S, Wu D, Zhao G, Zhang X. Assessment of Upper Limb Motor Dysfunction for Children with Cerebral Palsy Based on Muscle Synergy Analysis. Front Hum Neurosci 11: 1-13, 2017.

Ting LH, Chvatal SA, Safavynia SA, Lucas McKay J. Review and perspective: neuromechanical considerations for predicting muscle activation patterns for movement. Int j numer method biomed eng 28: 1003-1014, 2012.

Vernooij CA, Rao G, Berton E, Retornaz F, Temprado J-J. The Effect of Aging on Muscular Dynamics Underlying Movement Patterns Changes. Front Aging Neurosci 8: 309, 2016.

Wang Y, Asaka T, Watanabe K. Multi-muscle synergies in elderly individuals: Preparation to a step made under the self-paced and reaction time instructions. Exp Brain Res 226: 463-472, 2013.

Wang Y, Watanabe K, Asaka T. Aging effect on muscle synergies in stepping forth during a forward perturbation. Eur J Appl Physiol 117: 201-211, 2017.

Winter DA. The Biomechanics and Motor Control of Human Gait: Normal, Elderly, and 
medRxiv preprint doi: https://doi.org/10.1101/2020.05.22.20110536; this version posted June 25, 2020. The copyright holder for this preprint (which was not certified by peer review) is the author/funder, who has granted medRxiv a license to display the preprint in perpetuity.

All rights reserved. No reuse allowed without permission.

\section{Pathological. Waterloo, Canada: University of Waterloo Press, 1991.}


medRxiv preprint doi: https://doi.org/10.1101/2020.05.22.20110536; this version posted June 25, 2020. The copyright holder for this preprint (which was not certified by peer review) is the author/funder, who has granted medRxiv a license to display the preprint in perpetuity.

All rights reserved. No reuse allowed without permission.

\section{Appendix}

\section{Additional Module Group Results}

The module activation timing profiles and muscle weightings of the individuals in the two, four, five, and six module groups were not statistically analyzed because each of these module groups contained just one participant from at least one population. Still, some interesting observations can be made between populations in the four and five module groups. Though the activation timing profiles and muscle weightings are qualitatively similar between the unimpaired younger and older adults in the four and five module groups, the KOA patient's modular control differs from that of the unimpaired populations. The KOA patient in the four module group required separate modules for the medial hamstrings and biceps femoris while both muscles were associated with the HAMS module in the unimpaired adults. In contrast, the fourth module was dominated by the rectus femoris in the unimpaired adults. In the five module group, the KOA patient's VAS module is dominated by activity across all three medial muscles/muscle groups crossing the knee: vastus medialis, medial gastrocnemius, and the medial hamstrings. In addition, the KOA patient's vastus lateralis has a moderate weighting on the BF module. Thus, though this KOA patient had a relatively high modular control complexity as measured by the number of required modules, the patient's VAS and BF modules are suggestive of a control strategy characterized by the selective co-activation of the medial and lateral muscles crossing the knee, respectively, which is not observed in unimpaired adults with the same level of modular control complexity. 
medRxiv preprint doi: https://doi.org/10.1101/2020.05.22.20110536; this version posted June 25, 2020. The copyright holder for this preprint (which was not certified by peer review) is the author/funder, who has granted medRxiv a license to display the preprint in perpetuity.

All rights reserved. No reuse allowed without permission.

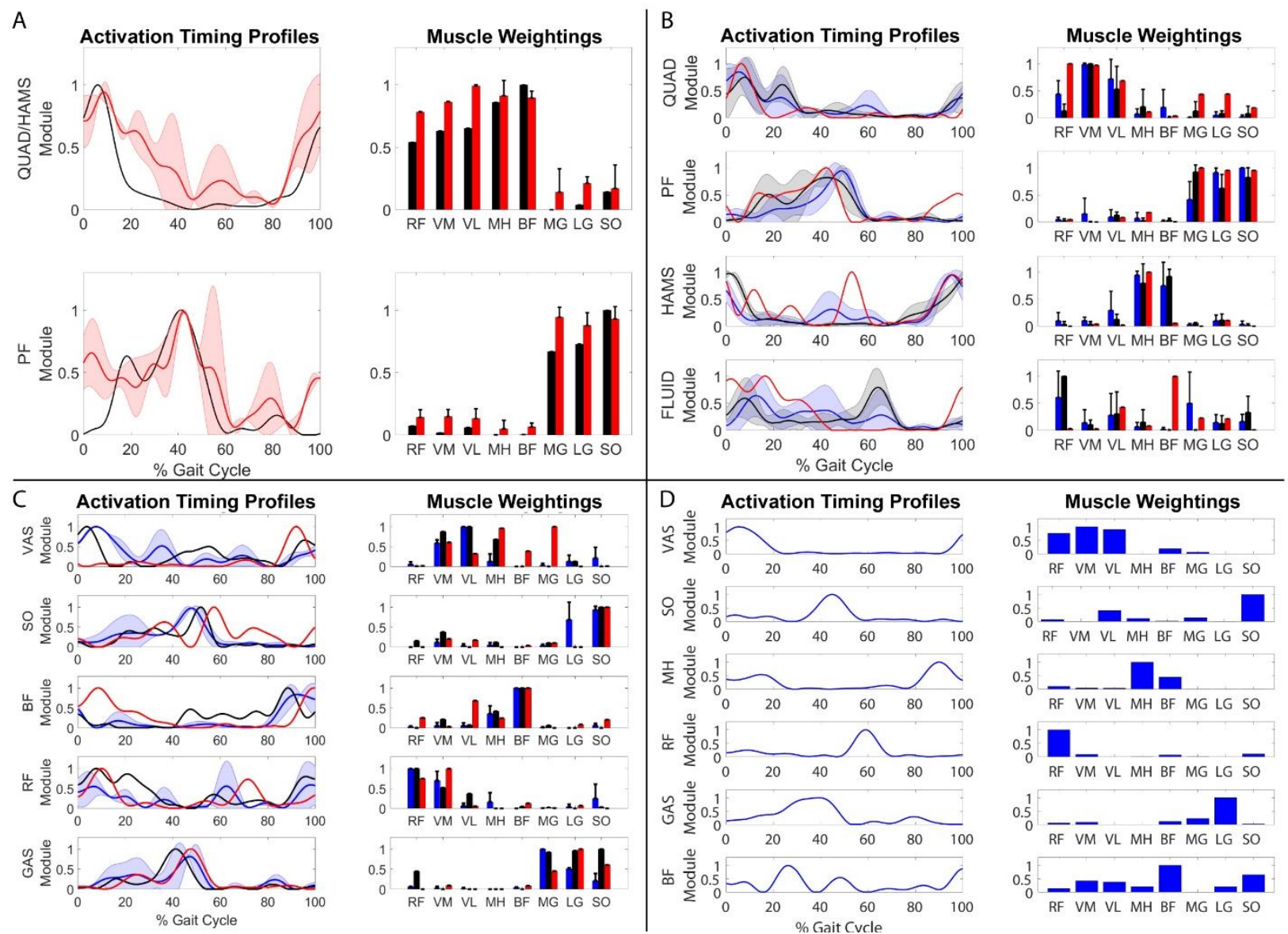

Figure A1: Module activation timing profiles and muscle weightings for A) two, B) four, C) five, and D) six module groups. Colors indicate population: younger adults in blue, older adult in black, and KOA patient in red. Muscle abbreviations: rectus femoris (RF), vastus medialis (VM), vastus lateralis $(\mathrm{VL})$, medial hamstrings $(\mathrm{MH})$, biceps femoris (BF), medial gastrocnemius (MG), lateral gastrocnemius (LG), and soleus (SO). Module name abbreviations: QUAD (quadriceps; RF, VM, and VL heavily weighted), PF (plantarflexors; MG, LG, and SO heavily weighted), HAMS (hamstrings; MH and BF heavily weighted), VAS (vasti; VM and VL heavily weighted), GAS (gastrocnemius; MG and LG heavily weighted) and FLUID (moderate weighting on multiple muscles). Modules named by a muscle abbreviation indicate that the muscle was the only heavily weighted muscle of the module. 
medRxiv preprint doi: https://doi.org/10.1101/2020.05.22.20110536; this version posted June 25, 2020. The copyright holder for this preprint (which was not certified by peer review) is the author/funder, who has granted medRxiv a license to display the preprint in perpetuity. All rights reserved. No reuse allowed without permission.
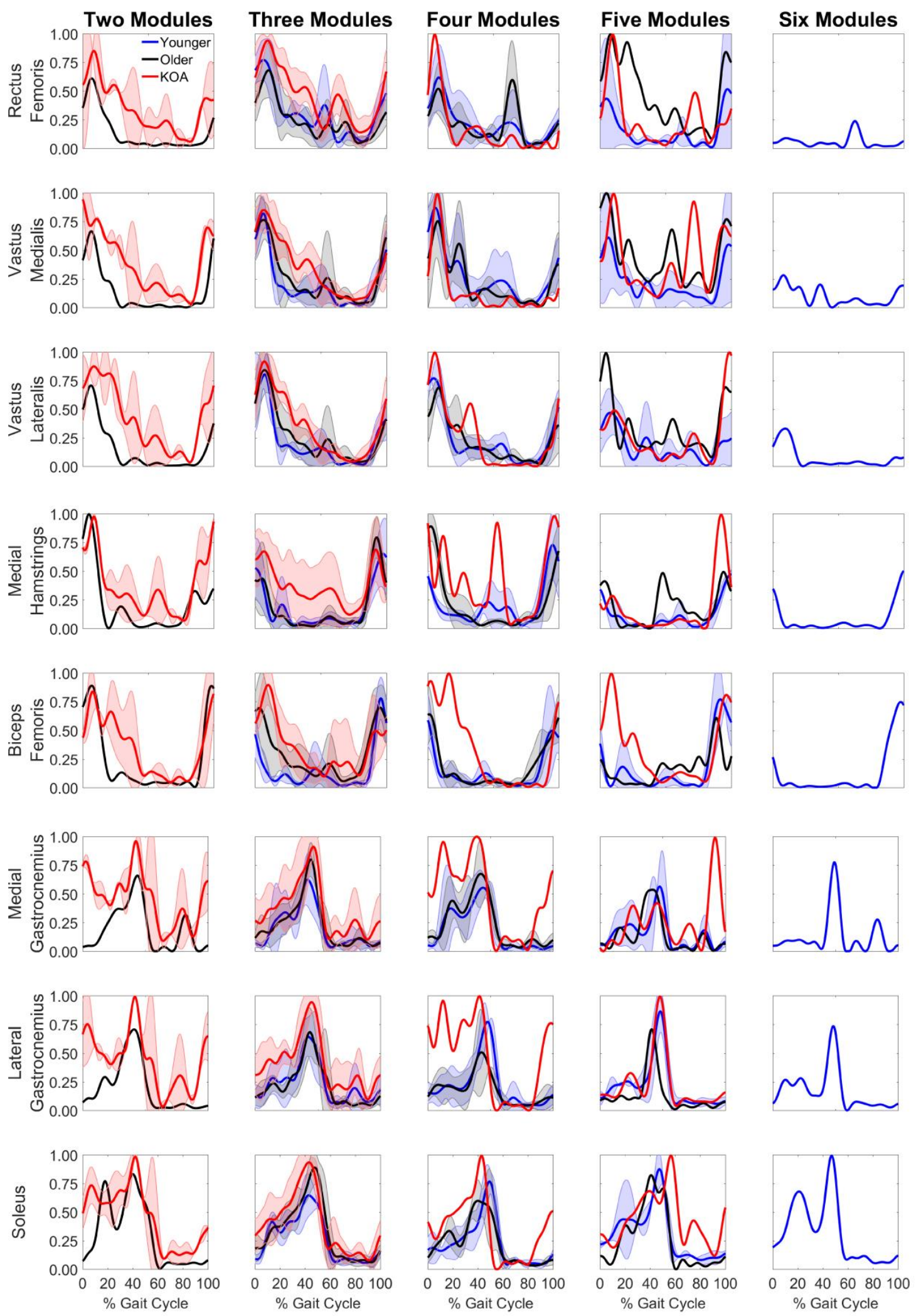

Figure A2: Average EMG of younger adults, older adults, and KOA patients by module group. Solid lines represent subject average. When appropriate, shaded error bars represent \pm one standard deviation. 